IZA DP No. 9574

New Job Matches and Their Stability

Before and During the Crisis

Amparo Nagore García

Arthur van Soest

December 2015

Forschungsinstitut

zur Zukunft der Arbeit

Institute for the Study

of Labor 


\title{
New Job Matches and Their Stability Before and During the Crisis
}

\author{
Amparo Nagore García \\ LISER \\ Arthur van Soest \\ Tilburg University \\ and IZA
}

\section{Discussion Paper No. 9574 \\ December 2015}

\author{
IZA \\ P.O. Box 7240 \\ 53072 Bonn \\ Germany \\ Phone: +49-228-3894-0 \\ Fax: +49-228-3894-180 \\ E-mail: iza@iza.org
}

Any opinions expressed here are those of the author(s) and not those of IZA. Research published in this series may include views on policy, but the institute itself takes no institutional policy positions. The IZA research network is committed to the IZA Guiding Principles of Research Integrity.

The Institute for the Study of Labor (IZA) in Bonn is a local and virtual international research center and a place of communication between science, politics and business. IZA is an independent nonprofit organization supported by Deutsche Post Foundation. The center is associated with the University of Bonn and offers a stimulating research environment through its international network, workshops and conferences, data service, project support, research visits and doctoral program. IZA engages in (i) original and internationally competitive research in all fields of labor economics, (ii) development of policy concepts, and (iii) dissemination of research results and concepts to the interested public.

IZA Discussion Papers often represent preliminary work and are circulated to encourage discussion. Citation of such a paper should account for its provisional character. A revised version may be available directly from the author. 
IZA Discussion Paper No. 9574

December 2015

\title{
ABSTRACT
}

\section{New Job Matches and Their Stability Before and During the Crisis*}

\begin{abstract}
Using administrative records data from the Spanish Social Security Administration, we analyse the nature and stability of job matches starting in two different years: during the economic boom in 2005, and during the recession in 2009. We compare the individual and job and firm characteristics in the two samples and estimate Mixed Proportional Hazard Models distinguishing job-to-job, job-to-unemployment, and other transitions. We find that job-to-job transitions are pro-cyclical, while unemployment transitions are counter-cyclical. Individuals most affected by the economic crisis tend to be young males, living in regions with high unemployment rates, with low qualifications and working in manual occupations (particularly construction), and (especially Spanish speaking) immigrants. The positive relation between job stability and firm size is stronger during the recession.
\end{abstract}

JEL Classification: J64, C41, E32

Keywords: job tenure, business cycle, employment transitions, destination states, job-separation rate

Corresponding author:

Arthur van Soest

Tilburg School of Economics and Management

Econometrics and Operations Research

Tilburg University

P.O. Box 90153

5000 LE Tilburg

The Netherlands

E-mail: a.h.o.vansoest@tilburguniversity.edu

\footnotetext{
* The authors wish to thank the Spanish Social Security for providing the data for this research and Maria Rochina Barrachina, Olga Cantó Sánchez, Hans Bloemen, Adriaan Kalwij, Jan van Ours, conference participants in Alicante and Montreal and seminar participants in Tilburg for useful comments. Amparo Nagore acknowledges financial support from University of Valencia (UV-INVEPDI14-185331 and UV-INV-PRECOMP14-207306).
} 


\section{Introduction}

The Great Recession has led to important adjustments in the labour market of most developed countries and has dramatically affected the labour market in Spain, which exhibits higher job destruction and lower job creation rates than other European countries. The goal of the Europe 2020 Strategy $^{1}$ "to create more and better jobs", emphasizes the necessity of assessing the nature and quality of new jobs over time. We contribute to this by studying the evolution of the characteristics of new job matches over the business cycle. An important indicator of the quality of a match is the duration of the job: better matches typically last longer. Accordingly, the 2015 country report for Spain of the European Commission (European Commission, 2015), emphasizes the promotion of stable employment as one of the challenges in the Spanish labour market.

In this paper, we examine shifts in the nature and stability of new job matches starting in 2005 and 2009 and decompose the changes in the stability of the new matches into variation in their composition and residual changes induced by changing economic conditions. The observation window for both samples is three years, so that we capture a period of expansion (2005-2007) and a period of recession (2009-2011). We particularly focus on the role of firm size and the differences in durations of new matches at small and large firms. By examining the shifts in job stability during boom and recession, we extend the scarce empirical evidence on cyclical fluctuations in the nature of new matches.

We consider as a new job match any new position of a worker at a new employer, or at a previous employer after an interruption by unemployment, non-employment, or employment at a different employer. Workers can be new entrants in the labour market, can come from unemployment, or can directly come from another job with a different employer. They can replace someone who left the same job, or they can get a newly created job - our data do not allow a distinction between these two possibilities.

During the downturn, the demand for labour falls, the number of voluntary job leavers typically falls and the number of unemployed workers rises. ${ }^{2}$ Added worker ${ }^{3}$ and discouraged

\footnotetext{
1 http://ec.europa.eu/europe2020/index_en.htm

2 See Longhi and Taylor (2013) for a comparison of the characteristics and behaviour of employed and unemployed job seekers over the business cycle.

${ }^{3}$ Added worker effect: Traditionally inactive groups, for instance married women, increase participation in the labour force to compensate for the unemployment of their husbands (primary workers).
} 
worker effects ${ }^{4}$ will affect labour supply, as well as emigration or return migration. The negative consequences of the rise in transitions to unemployment are well-known. But the decline in job-to-job transitions is also a concern, since it may reduce efficiency of the labour market and productivity growth or affect working conditions. ${ }^{5}$ Demand and supply forces may work in opposite directions. For instance, during the downturn, the employer may recruit better workers because of the larger applicant pool. On the other hand, workers may be willing to accept matches that they would reject in expansion periods. Job search and matching theory (Jovanovic, 1979) imply that during the downturn, lower expectations of the workers to improve job conditions reduce job-to-job transitions, increasing the durations of new jobs. Moreover, the decline in expected productivity during the downturn raises the number of layoffs and shortens job tenure.

The data we use come from the Longitudinal Working Lives Sample, based upon administrative records from the Spanish Social Security Administration. It contains detailed information on employment and unemployment transitions and individual and job characteristics. We construct two separate samples with job spells starting in 2005 and 2009, observing the job entrants until either job exit or the end of the observation period. These samples therefore certainly do not represent all employees. ${ }^{6}$

As pointed out by Bergmann and Mertens (2011), more insight in the opposing forces at work can be obtained by considering the exits to different destination states. We therefore estimate Mixed Proportional Hazard (MPH) Models with three destination states: other job, unemployment and non-employment. To allow for dependence among the three hazards, unobserved heterogeneity in these hazards is modelled jointly, using a discrete distribution with three points of support.

Explanatory variables include individual and job characteristics, and regional unemployment. We particularly focus on differences between large and small firms. It is wellknown that larger firms have lower turnover (Haltiwanger et al., 2015), but there exist

\footnotetext{
${ }^{4}$ Discouraged worker effect: The unemployed give up search because of the low chances to find a job.

${ }^{5}$ Lentz and Mortensen (2005) argue that "worker reallocation among firms is an important source of productivity growth". Davis and Haltiwanger (2014) show that the drop in the rate of job-to-job transitions contributes to the declining employment rates especially for marginally attached workers. Hyatt and McEntarfer (2012) find that "job change is an important component of earnings growth over worker careers".

${ }^{6}$ The reason is that entry into a new job match is not random. Our sample includes those who start in a new job in a given year and will underrepresent workers with stable employment or unemployment. To account for this selection problem one could in principle model this and include every adult; see, e.g., Kalwij (2004).
} 
opposing views on how firms of different sizes respond to the business cycle. The policy relevance seems obvious. Government policies that stimulate starting a new firm to create employment have been criticized because the stability of new jobs at small firms is often inferior, and these policies can hamper firm growth (Shane, 2009). It seems relevant to analyse to which extent this also applies to Spain in the years of the crisis. In the Spanish policy debate, it has already been suggested that larger firms are necessary to increase productivity and stable employment (Pérez, 2014 and Consejo Empresarial para la Competitividad, 2014) and penetration in foreign markets (European Commission, 2015).

The remainder of this paper is organized as follows. Section 2 presents a brief review of the literature. Section 3 describes the data. Section 4 presents the characteristics and job exit patterns of new jobs. Section 5 introduces the econometric framework of job durations. Section 6 provides the main results. Conclusions are drawn in section 7.

\section{Literature review}

In this section we first discuss the literature on the composition of new matches over the business cycle and the cyclical fluctuations in job stability.

\subsection{The nature of new job matches over the business cycle}

Devereux (2002) examines how in the US the educational composition of new matches within a given occupation changes over the business cycle. He finds counter-cyclicality in the quality of workers hired, especially in lower paying occupations, implying that less skilled workers have more pro-cyclical job finding rates. Also for the US, Devereux (2004) explores the cyclical quality adjustment of new hires, showing that new matches result in lower quality jobs in recessions than in booms and that part of the wage pro-cyclicality in new matches can be attributed to the variation in quality of the matches over the business cycle. Similarly, van Ours and Ridder (1995), using Dutch data on unemployed workers only, found that jobs obtained in recessions are less attractive. For the same country, Teulings (1993) found that involuntary job seekers (workers who expect to be dismissed in the near future) get better jobs during an upswing than during a downturn. De la Roca (2014) found that in Spain, the sensitivity of wages for the economic cycle declines with tenure and, accordingly, is highest for newly-hired workers. Alba-Ramirez (1991) studied changes in the characteristics of new 
jobs in the mid-70s and the mid-80s in Spain and found that job losers are among the most disadvantaged groups.

The evolution of employment has been extensively explored by public institutions because of its policy relevance. For instance, Eurofound (2013) describes the net employment evolution for EU countries before, during and after the 2008-2010 recession, disaggregating by worker characteristics and employment status. They identify the groups most affected by the crisis, such as young male workers, those with low education levels, and those with temporary contracts. The industries with most job destruction are manufacturing and construction. They also point at the persistence of some longer-term trends, like higher expansion in high-skill employment, improvement in female employment both in qualitative and quantitative terms, and a strong growth in part-time work and self-employment.

Several Spanish studies analyse the effects of the current crisis on employment using data from Economically Active Population Survey (EPA). Rocha and Aragón (2012) explored the evolution of net employment between 2008 and 2012, pointing out the increased concentration of employment in very large and very small firms, as well as in high skilled and medium-low occupations. They also showed that construction and manufacturing are the sectors with most job destruction during the crisis, affecting mainly young, male, low-skilled, and immigrant workers. García-Serrano (2012) investigated the evolution of employment at sector and occupational level for the period 1985-2011 at turning points in the economic cycle, emphasizing the different evolution and pro-cyclical nature of the construction sector in Spain compared to other European countries.

\subsection{Cyclicality of the durations of new jobs}

Although job stability has been studied much less extensively than unemployment duration, its importance is well established in the literature. From a worker's perspective, job duration influences future prospects, like the development of human capital, wage levels and welfare state entitlements (Keith and Mc Williams, 1995; Heinz, 2006). From an employer's perspective, separation rates determine employer policies on, e.g., human capital investment, promotions, and wages (Hirsch and Schnabel, 2012).

There is little empirical work on the changes in the stability of new matches over the business cycle. For young males in the US, Bowlus (1995) found that mismatching occurs more during recessions and is primarily captured in starting wages. Many studies have focused on 
changes over time in mean job tenure in countries with different levels of employment protection (see Boockman and Steffes, 2010, for references), but these studies focus on secular changes rather than cyclicality.

Studies that focus on the individual determinants of job stability usually include controls for the economic conditions. Boockman and Steffes (2010) incorporate institutional and historical variables. Most of these studies distinguish several destination states (Frederiksen, 2008; Boockmann and Steffes, 2010; Hirsch and Schnabel 2012; Bratberg et al. 2010; Theodossiou and Zangelidis, 2009), reasons for job termination (Booth et al., 1999) or both (Bergmann and Mertens, 2011). Dütsch and Struck (2014) extend previous research on how firm characteristics and regional economic conditions influence mobility in the German labour market. For 1999 and 2002, years that are representative of the two cyclical phases, they find that firm's investments in training and internal promotion opportunities (typically taking place in larger firms) foster employment stability, while the opposite happens with the extensive use of fixed-term contracts.

For Spain, García-Pérez (1997) and García-Perez and Muñoz-Bullón (2005) used social security records to study patterns and determinants of transitions into and out of employment (involuntary turnover). The latter study emphasizes the role of Temporary Help Agencies in workers' transitions. Arranz and García-Serrano (2004) explored the influence of previous labour market experience on exit rates by reason for termination (end of a contract and layoff). Blázquez-Cuesta (2008) distinguished job separations by destination states (other job and non-employment) for the period 1995-2001 with special attention for low paid workers. Rebollo (2012) focused on the relationship between the unemployment insurance and different labour market transitions.

According to the theory of labour market segmentation, large establishments tend to create circumstances that foster employment stability. Empirical studies based on individual level data typically find that job exit rates are indeed significantly lower in larger firms (Bergmann and Mertens, 2011; Boockmann and Hagen, 2008; Rebitzer, 1986; BlázquezCuesta, 2008; Rebollo, 2012; Dütsch and Struck, 2014). On the other hand, studies based on linked employer-employee data (Boockmann and Steffes, 2010; Hirsch and Schnabel, 2012; Martin, 2003) find that it is not firm size as such that matters, but factors correlated with firm size like the presence of works councils or unions, availability of further training, and the amount of firm specific technology. There is also evidence that some characteristics of large 
firms help to enhance employment stability, such as more training opportunities, more job flexibility and possibilities of promotion within the firm, and a better ability to adjust the production process to economic shocks (Struck, 2006). The latter also suggests that job stability would suffer less during the crisis in large firms than in small firms.

Still, there exists ambiguity in the literature related to the role of firm size on cyclical employment. One strand, starting with Gertler and Gilchrist (1994), argues that small businesses are more sensitive to cyclical economic shocks than larger firms, due to their stronger credit constraints. Sharpe (1994) finds that small firms more easily lay off workers during a recession, but not faster to hire during an expansion. Davis and Haltiwanger (2001) find that industries with a large share of young, small plants are more sensitive to cyclical credit market shocks. This evidence is also supported by Fort et al. (2013). The opposite argument is based on the greater ability of large firms to increase employment in the expansion period and their subsequent greater need to lay off workers during the downturns. This prediction stems from the dynamic models of Moscarini and Postel-Vinay (2009, 2012, 2013) and is supported by the evidence of Kahn and McEntarfer (2014). Fort et al. (2013) point out that some of the differences found in the empirical literature are related to the cyclical indicators used and the types of shocks measured.

Shane (2009) argues that the jobs created in small firms are often unstable and not productive. He therefore proposes to eliminate the barriers for firms to grow (such as lower taxation or subsidies for small firms) and stimulate high growth companies (through, e.g., R\&D tax credits). Accordingly, European Commission (2015) points out that the challenge for policies concerning small and medium enterprises is to support company creation while at the same time setting out conditions for company growth. Pérez (2014) and Consejo Empresarial para la Competitividad (2014) emphasize that the number of new firms created in Spain is not that small compared to other countries, but the new firms are typically small, have low survival chances, and do not create permanent employment. Creating stable jobs requires eliminating barriers to firm growth such as subsidies for small firms only or inefficacy in the legal system (García-Posada and Mora, 2013), combined with policies that stimulate firm growth through productivity, e.g., investment, R\&D, and professional training (Huerta and Salas, 2014). 


\section{Data}

The data we use come from the Longitudinal Working Lives Sample ${ }^{7}$ (LWLS), based upon administrative records from the Spanish Social Security Administration (SSA). The LWLS is collected annually since 2004 and contains information on a 4 percent random sample of the population (approximately one million people) who ever had any sort of relationship with the $\mathrm{SSA}^{8}$ in the sample period, as contributor or benefit recipient. Individuals in the 2004 LWLS remain in the sample as long as they have a relationship with SSA, making it possible to analyse labour market changes over time. LWLS provides rich information on individual characteristics and firm and job attributes such as firm size, sector of activity, annual wages and type of contract. ${ }^{9}$

To compare the expansion and recession periods, we construct two samples that include job spells (excluding self-employment) that started in 2005 and in 2009, observing the workers with a new job match until the end of the job spell or the observation period. The latter is 31 December 2011 for the 2009 data and is set to 31 December 2007 for the 2005 data (to increase comparability). This is achieved by merging the data sets LWLS 2005-20062007 and LWLS 2009-2010-2011.

We apply several filters to our samples, described in detail in the appendix (Table A2). For instance, our samples are restricted to workers aged 16 to 53 in the year of reference, avoiding exits through an early retirement option. We remove individuals with incomplete information and recode overlapping spells. ${ }^{10}$ Moreover, we only include job spells that last at least 31 days (after recoding) since very short spells can normally not be considered as real jobs and would require a separate model. We do not consider workers from the agricultural sector because of the particular rules in this sector ("Agrarian Special Regime") and dropped observations from Ceuta and Melilla (two small Spanish enclaves in Africa).

As explained in Section 1, the immediate destination states (within 31 days after the end of the job spell) we distinguish are: finding another job (including self-employment), transition to unemployment with benefits, and exit to non-employment. They are explained in detail in Table 1.

\footnotetext{
${ }^{7}$ We use the LWLS version with fiscal data.

${ }^{8}$ Civil servants are not included in the LWLS.

${ }^{9}$ We use the tax information to obtain information on wages. See Arranz and García-Serrano (2011).

${ }^{10}$ The consecutive criteria applied to preserve spells corresponding to the main activity are: we keep the spells with 1) the highest part-time coefficient, 2) with the longest spell, and 3) with the highest contributory base. The remainder of overlapping spells is removed.
} 
Table 1: Definition of destination states

\begin{tabular}{ll} 
Destination states & \multicolumn{1}{c}{ Definition } \\
\hline Other job & $\begin{array}{l}\text { Immediate job spell of at least 31 days within 31 days after the end of the job under } \\
\text { study. It includes transitions to a new employer and self-employment. }\end{array}$ \\
\hline $\begin{array}{l}\text { Unemployment } \\
\text { with benefits }\end{array}$ & $\begin{array}{l}\text { Immediate unemployment benefit spell of at least 31 days of contributory and/or } \\
\text { social assistance benefits within 31 days after the end of the job under study. }\end{array}$ \\
\hline $\begin{array}{l}\text { Non-employment } \\
\text { state }\end{array}$ & $\begin{array}{l}\text { Defined as the residual group. Includes unemployment without benefits, } \\
\text { emigration, black economy and inactivity (for instance to care for family or to } \\
\text { become a student). } \\
\text { This state is identified if there is no subsequent job spell (of at least 31 days) and } \\
\text { no spell with unemployment benefits (of at least 31 days) within 31 days after the } \\
\text { end of the job under study. }\end{array}$ \\
\hline
\end{tabular}

Consecutive job spells with the same employer and a difference shorter than 32 days are considered as one job spell, with the characteristics of the first contract. This limit of 31 days and the requirement that the duration of the new spell is at least 31 days help to avoid considering the strategic use of unemployment benefits as job-to-unemployment transition. Job duration is defined as the difference (in days) between the termination date and the starting date of the job. If at the end of the observation period the employee is still working for the same employer, data are considered right censored.

Our samples consist of 176,419 individuals starting 222,125 new job spells in 2005, and 141,153 employees with 170,249 new jobs spells in 2009 . The difference between the two samples reflects the substantial drop in the number of new jobs between 2005 and 2009.

\section{Characteristics of new job matches before and during the crisis}

New job matches are the result of the interaction of job searchers and firms. The business cycle may lead to changes in the pool of job searchers and in the job assignment process, shifting the sample composition of new job starters. To explore the cyclical sample composition variation we compare descriptive statistics of individual and job characteristics of new job starters in the two years (Table 2). The importance of the crisis is reflected in the substantial growth of the average regional unemployment rate. During the recession period, the proportion of younger individuals (16-29 years old) in new matches decreases, while the proportion of workers older than 35 increases. In a context of excess supply of labour, employers hire more experienced workers, in line with the finding of Devereux (2004). 
Table 2: Descriptive statistics for the 2005 and 2009 samples

\begin{tabular}{|c|c|c|c|c|}
\hline \multirow[b]{2}{*}{ Variable } & \multicolumn{2}{|c|}{2005} & \multicolumn{2}{|c|}{2009} \\
\hline & Mean & Std. Dev & Mean & Std. Dev \\
\hline \multicolumn{5}{|c|}{ MACROECONOMIC VARIABLES } \\
\hline Unemployment rate (quarterly) & 0.09 & 0.04 & 0.20 & 0.05 \\
\hline Male unemployment rate (quarterly) & 0.07 & 0.021 & 0.19 & 0.05 \\
\hline Female unemployment rate of (quarterly) & 0.11 & 0.043 & 0.20 & 0.06 \\
\hline Inhabitants $>40,000(*)$ & 0.45 & 0.498 & 0.48 & 0.50 \\
\hline \multicolumn{5}{|c|}{ INDIVIDUAL CHARACTERISTICS } \\
\hline Male (*) & 0.54 & 0.50 & 0.51 & 0.50 \\
\hline Age at the year of starting the job spell & 32 & 9.09 & 34 & 9.22 \\
\hline \multicolumn{5}{|l|}{ Nationality } \\
\hline Spanish native $\left({ }^{*}\right)$ & 0.89 & 0.31 & 0.85 & 0.36 \\
\hline Spanish speaking immigrant $\left({ }^{*}\right)$ & 0.05 & 0.22 & 0.05 & 0.22 \\
\hline Non Spanish speaking immigrant $\left({ }^{*}\right)$ & 0.06 & 0.23 & 0.10 & 0.30 \\
\hline Children<4 $(*)$ & 0.11 & 0.32 & 0.13 & 0.33 \\
\hline Children $>3 \&<16(*)$ & 0.20 & 0.40 & 0.22 & 0.42 \\
\hline \multicolumn{5}{|l|}{ Level of education } \\
\hline Primary_education $(*)$ & 0.18 & 0.39 & 0.19 & 0.39 \\
\hline Lower_secondary $\left({ }^{*}\right)$ & 0.40 & 0.49 & 0.40 & 0.49 \\
\hline Upper secondary (*) & 0.25 & 0.43 & 0.24 & 0.43 \\
\hline Post-secondary $(*)$ & 0.16 & 0.37 & 0.16 & 0.37 \\
\hline \multicolumn{5}{|c|}{ JOB CHARACTERISTICS } \\
\hline Non-Manual occupation $\left({ }^{*}\right)$ & 0.41 & 0.49 & 0.42 & 0.49 \\
\hline \multicolumn{5}{|l|}{ Industry } \\
\hline Construction $\left({ }^{*}\right)$ & 0.18 & 0.38 & 0.15 & 0.36 \\
\hline Manufacturing $(*)$ & 0.11 & 0.32 & 0.08 & 0.27 \\
\hline Services $(*)$ & 0.71 & 0.45 & 0.77 & 0.42 \\
\hline High technology (*) & 0.09 & 0.28 & 0.03 & 0.17 \\
\hline \multicolumn{5}{|l|}{ Firm size } \\
\hline Firm size missing $(*)$ & 0.05 & 0.21 & 0.03 & 0.18 \\
\hline Size_1_9 (*) & 0.29 & 0.45 & 0.34 & 0.47 \\
\hline Size_10_19 $\left(^{*}\right)$ & 0.12 & 0.32 & 0.11 & 0.32 \\
\hline Size_20_49 $(*)$ & 0.15 & 0.36 & 0.14 & 0.35 \\
\hline Size_50-249 (*) & 0.20 & 0.40 & 0.19 & 0.40 \\
\hline Size_250 (*) & 0.19 & 0.40 & 0.18 & 0.38 \\
\hline \multicolumn{5}{|l|}{ Type of contract } \\
\hline Current contract is temporary $\left({ }^{*}\right)$ & 0.64 & 0.48 & 0.62 & 0.48 \\
\hline Current contract is on-call temporary $\left({ }^{*}\right)$ & 0.06 & 0.23 & 0.07 & 0.26 \\
\hline Current contract is open-ended $(*)$ & 0.03 & 0.17 & 0.05 & 0.23 \\
\hline Current contract is permanent $\left({ }^{*}\right)$ & 0.27 & 0.44 & 0.25 & 0.43 \\
\hline Current contract is part-time $\left({ }^{*}\right)$ & 0.22 & 0.41 & 0.28 & 0.45 \\
\hline Temporary Help Agency (*) & 0.04 & 0.20 & 0.03 & 0.18 \\
\hline Public Sector $(*)$ & 0.08 & 0.27 & 0.10 & 0.31 \\
\hline Real daily wage (euros in 2009) (**) & 50 & 24.34 & 54 & 27.37 \\
\hline
\end{tabular}

Source: Own calculations using LWLS and the Spanish Labour Force Survey (quarterly regional unemployment rate). Note: Descriptive characteristics corresponding to the first observation of each individual in each sample. $\left(^{*}\right)$ Dummy variables, $\left(^{* *}\right)$ Real daily wages for full time Jobs. According to t-tests, all differences in means between both samples are statistically significant except for Lower secondary and Post-secondary school). Variable definitions are given in Table A1 (Appendix).

The drop of the fraction of males (from $54 \%$ in 2005 to $51 \%$ in 2009) may be due to an added worker effect, or to the overrepresentation of males in declining sectors 
(manufacturing and construction), while women are often employed in growing sectors like health and education.

Only 32\% (35\%) of the sample individuals have dependent children (younger than 16 years old) in the expansion (recession) period. The proportion of Spanish natives in new matches declined from $89 \%$ in 2005 to $85 \%$ in 2009 . The proportion of non-Spanish speaking immigrants rose from $6 \%$ to $10 \%$, possibly due to the surge of immigrants in the pool of job searchers due to job loss.

The distribution of education level of the new matches remains stable. Most individuals (40\%) have lower secondary level of education while only $16 \%$ have postsecondary level. The proportion of new job starters in non-manual occupations increases slightly from $41 \%$ in 2005 to $42 \%$ in 2009 . Degree of urbanization is captured by a dummy for living in a larger municipality. Around $45 \%$ of workers live in a municipality with more than 40,000 inhabitants in 2005 and 48\% in 2009.

The job characteristics we consider relate to sector of activity, type of contract, firm size, and daily salary. Sectors of activity are grouped into construction, services and manufacturing industry. Most workers who started a new job in 2005 did it in the services sector (71\%). The proportions in the manufacturing and construction sectors fell from $11 \%$ to $8 \%$ and from $18 \%$ to $15 \%$ with the burst of the property bubble, respectively. This fits with the pro-cyclical nature of the construction sector and the decrease in industrial employment during recessions found in García-Serrano (2012). In 2005, 9\% of new job matches are in sectors with a high level of technology; this fell dramatically to only $3 \%$ during the recession.

The majority of the new contracts are temporary, about $74 \%$ in both periods. Openended contracts are especially set up for seasonal activities, as they allow for interruptions of the employment relation due to seasonality. This type of contract is found in about $3 \%(5 \%)$ of the new jobs in 2005 (2009). The proportion of part-time contracts is lower than the European average (Labour Force Survey, 2009), but new part time contracts became more common ( $22 \%$ in 2005 versus $28 \%$ in 2009$)$.

The fraction of new jobs signed through Temporary Help Agencies (THA) acting as an intermediary, declined from $4 \%$ in 2005 to $3 \%$ in 2009. This fall may seem surprising given that the main service provided by the THAs is just-in-time labour that helps firms to adjust to demand fluctuations (Amuedo-Dorantes et al., 2008) and is more necessary in uncertain periods. Possibly the fall is a consequence of the fact that THA contracts are more common 
for younger and low-qualified workers, larger firms, and more inhabited regions, groups that exhibit a higher reduction in hiring in 2009.

The proportion of new hires in the public sector (excluding civil servants) has increased from $8 \%$ in 2005 to $10 \%$ in 2009 . This growth may be explained by the employment creation in public sector industries such as education and health. It may also be influenced by the increased tendency of the public sector to hire through labour contracts instead of in the form of civil service employment, in a context of public spending cuts.

The average real daily wage in a new job increased from $€ 50$ in 2005 to $€ 54$ in 2009 sample. ${ }^{11}$ The percentiles in Table 3 show that the rise in wages is non-uniform: higher paid jobs exhibit greater wage growth than mid and low paid new jobs. A possible explanation of the greater wages growth in higher paid jobs is, in line with Devereux (2002), that the abilities of workers hired might be higher in recessions as during a recession, the tasks within occupation require better skills.

Table 3: Percentiles and variation in the real daily wage in new job matches in 2005 and 2009

\begin{tabular}{ccccc} 
& & & \multicolumn{2}{c}{ Variation } \\
\cline { 4 - 5 } Percentiles & $\mathbf{2 0 0 5}$ & $\mathbf{2 0 0 9}$ & Absolute & Relative \\
\hline $1 \%$ & 18.15 & 19.49 & 1.34 & $7 \%$ \\
$5 \%$ & 25.61 & 27.47 & 1.86 & $7 \%$ \\
$10 \%$ & 29.55 & 31.52 & 1.97 & $7 \%$ \\
$25 \%$ & 36.20 & 38.47 & 2.27 & $6 \%$ \\
$50 \%$ & 43.48 & 46.93 & 3.44 & $8 \%$ \\
$75 \%$ & 55.39 & 60.53 & 5.14 & $9 \%$ \\
$90 \%$ & 77.98 & 86.05 & 8.06 & $10 \%$ \\
$95 \%$ & 98.44 & 109.39 & 10.95 & $11 \%$ \\
$99 \%$ & 152.19 & 169.35 & 17.16 & $11 \%$
\end{tabular}

Note: Own elaboration from the real daily wage at the start of a new job. Part-time jobs excluded.

To sum up, the changes in sample composition reveal interesting facts that are in line with previous studies: first, the marked sectorial character of this crisis and the dramatic reduction in high technology intensive jobs. Second, the growth of the share of new hires in micro-enterprises during the crisis. Third, the countercyclical nature of the number of part time jobs. Fourth, the surge in the demand for labour in public services as well as the growing

\footnotetext{
${ }^{11}$ Both amounts in euros in 2009, deflated by the average annual CPI of base 2011, and referred to full-time jobs.
} 
trend in hiring through labour contracts. Finally, higher growth in real wages in high-paid jobs than in low and medium paid jobs.

\section{Job exits before and during the crisis}

The fraction of job separations over the total observation window is high and rather similar in both periods: $77 \%$ of the new matches in 2005 and $82 \%$ in 2009 ended within three years. This reveals the importance of the job turnover in the Spanish labour market (Dolado et al. 2002), especially for new employees according to the LIFO (Last in, First Out) scheme. ${ }^{12}$ It appears to be driven by two opposite processes: the pro-cyclical nature of transitions to other jobs (29\% in 2005 and $18 \%$ in 2009) and to non-employment (33\% in 2005 and 30\% in 2009), and the counter-cyclical nature of job-to-unemployment rates (16\% in 2005 and 34\% in 2009). Job-to-job exits dominate in the expansion period, while job-to-unemployment transitions dominate during the crisis. The aggregated job-to-any-exit hazard (not shown) combines very distinct outflows correlating differently with the business cycle, hindering the interpretation and confirming the necessity to estimate job separation hazards by destination state.

Figure 1 shows separate Kaplan Meier survival functions for exits to another job, unemployment, and non-employment (treating other types of exits as right-censoring). For example, the probability that an employed changed to another job within a year fell from $34 \%$ in 2005 to $23 \%$ in 2009 , but the probability to become unemployed within a year increased from $23 \%$ to $43 \%$. Survival functions for exits to unemployment and other job show a greater decline after 180 and 360 days of employment, perhaps due to the higher incidence of temporary employment. The probability of a transition from a job to non-employment within one year fell from $41 \%$ to $38 \%$. It is not clear what should be expected here due to the residual character of this exit, which combines voluntary exits from the labour market with involuntary exits of fired workers who are not entitled to unemployment benefits.

The hazard rates corresponding to these survival functions are sketched in Figure $2 .{ }^{13}$ The empirical hazard rate at time $t$ is the proportion of individuals employed for at least $t$ days

\footnotetext{
12 The LIFO scheme is due to the lower dismissal costs associated with shorter job tenures. Cueto and Rodriguez (2013) show that the use of the LIFO scheme is becoming slightly weaker since 2010, but it is not clear whether this is because of the 2010 labour market reform or the economic crisis.

${ }^{13}$ The estimates use Kernel smoothing.
} 
that leave the job on day $t+1$ for the given destination. Figure 2 shows some local peaks in the hazards at 90, 180, 270 and 360 days. These peaks are also found in previous studies and correspond to the usual durations of temporary contracts. The negative association between hazard rate and job tenure, with the exception of the peaks, is found for all exits. This may reflect genuine negative state dependence or spurious negative state dependence due to heterogeneity and the changing nature of the pool of workers in the new matches over time. These explanations will be disentangled in the econometric model.

Figure 1: Kaplan Meier Survival estimates; Exits from employment to other job, unemployment and non-employment. 2005 and 2009 samples. Durations in days

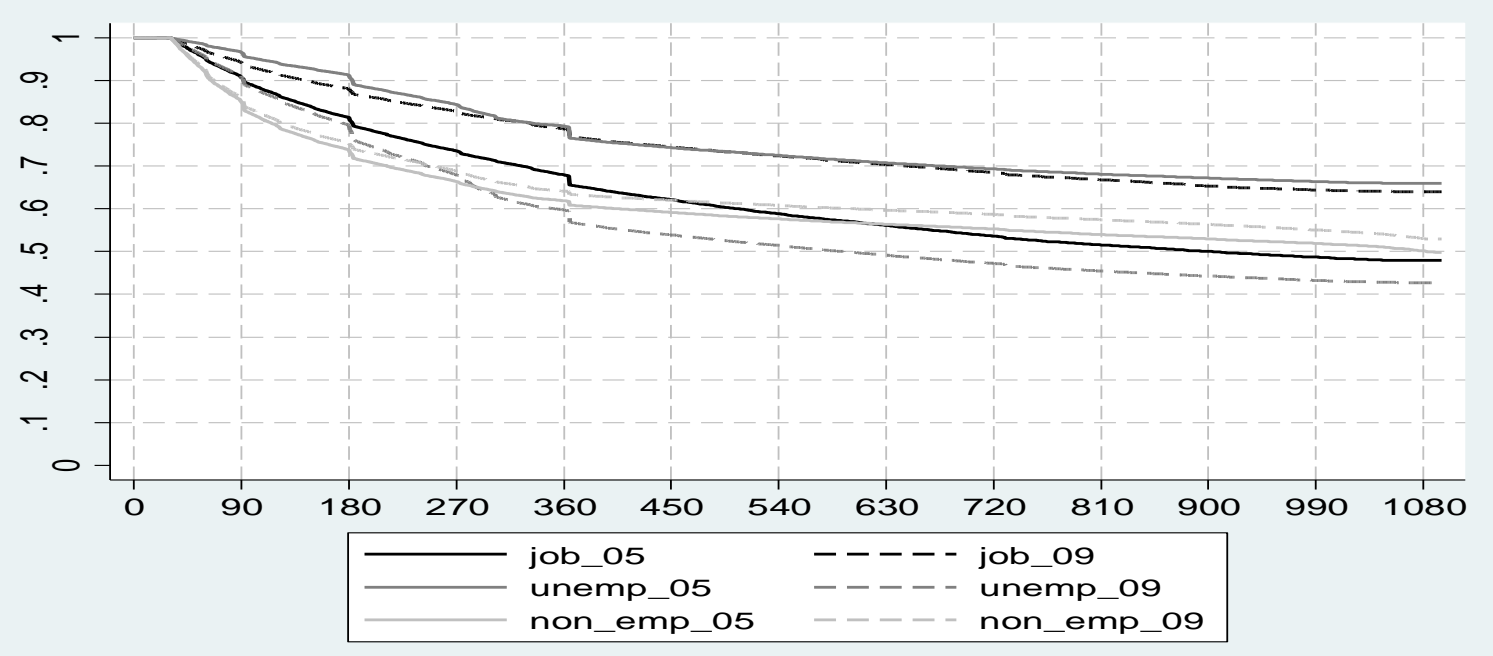

Source: Own elaboration from LWLS.

Figure 2: Kaplan Meier kernel hazard functions; exits from employment to other job, unemployment and non-employment. 2005 and 2009 samples. Durations in days

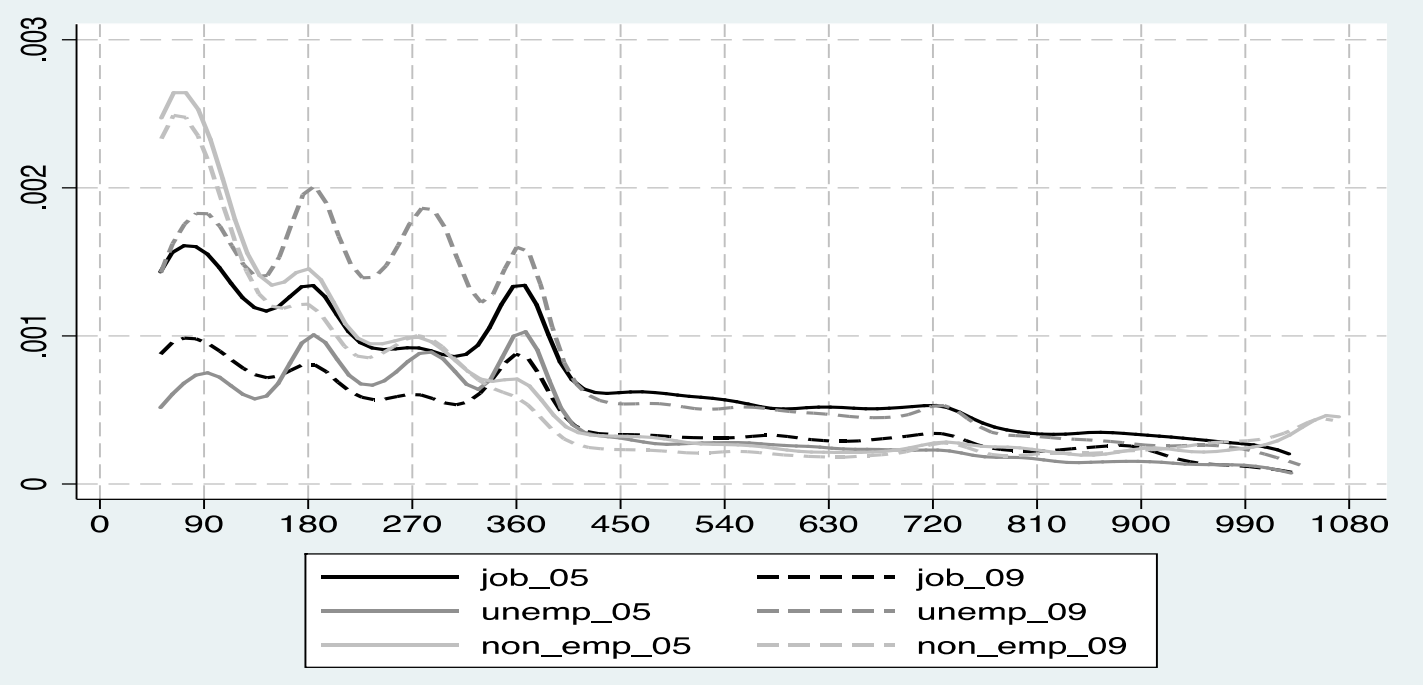

Source: Own elaboration from $L W L S$. 


\section{Econometric framework for job stability analysis: Competing risks model}

To analyse the pattern and determinants of job stability we use a competing risk model (distinguishing between exits to other job, unemployment and non-employment). We consider the duration of each job spell as a continuous random variable since job durations are measured in days. To study the determinants of transitions to another job, unemployment, and non-employment, we use a a competing risks framework (see, e.g., Kalbfleisch and Prentice, 2002, Chapter 8). A job spell can end with a transition to another job $(j=1)$, an unemployment with benefits $(j=2)$, or non-employment $(j=3)$. This gives the total hazard

$$
h(t)=h_{1}(t)+h_{2}(t)+h_{3}(t)
$$

Here $h(t)$ is the hazard to exit from the employment spell to any destination state at job duration $t$, and $h_{1}(t), h_{2}(t)$ and $h_{3}(t)$ are the hazards for exits to the three competing exits. Conditional on observed and unobserved heterogeneity, the competing risks are assumed to be independent. We specify the following Multivariate Mixed Proportional Hazard (MMPH) model with gap-time representation ${ }^{14}$ with hazards $h_{j}\left(t \mid X_{i}(t), V_{i}^{j}\right)$ for the three types of transitions $j=1-3$, of individual $i$ conditional on observed and unobserved characteristics:

$$
h_{j}\left(t \mid X_{i}(t), V_{i}^{j}\right)=h_{0}^{j}(t) \cdot \exp \left(X_{i}(t)^{\prime} \beta^{j}\right) \cdot \exp \left(V_{i}^{j}\right)
$$

The baseline hazard for the transitions $j=1-3, h_{0}^{j}(t)$, is specified as piecewise constant (using mainly quarterly cut-points):

$$
h^{j}{ }_{0}(t)=\bar{h}^{j}{ }_{k} t \in\left(\tau_{k-1}, \tau_{k}\right), k=1, \ldots, K
$$

This specification has the advantage of not imposing a particular functional form, allowing for a flexible shape of duration dependence.

The parameters of main interest are the vectors $\beta^{j}, j=1,2,3$, which determine how the three hazards vary with individual and job characteristics. A positive coefficient in $\beta^{j}$ of a covariate implies that, conditional on other covariates and unobserved heterogeneity, an increase of the covariates increases the probability of exit $j$. A way to interpret the size of the coefficients is through the percentage change in the hazard produced by a one unit change in the covariate, obtained as $\left(e^{\beta_{j}}-1\right) \cdot 100$.

The proportional hazard assumption implies that the shape of the duration dependence ("baseline hazard") for each exit is the same for all individuals; the covariates

\footnotetext{
${ }^{14}$ Gap time representation: time is reset to zero after each event (see, e.g., Van den Berg, 2001).
} 
change the hazard rates with the same proportion at each $t$, so the level of the hazard may change across individuals.

Ignoring unobserved heterogeneity may lead to biases in the estimates of $B$ and would make the estimated duration dependence more negative (Nickell, 1979). The unobserved heterogeneity terms are $V_{i}^{j}$. Following Heckman and Singer (1984), we use discrete frailty and allow $V_{i}^{1}, V_{i}^{2}$ and $V_{i}^{3}$ to be correlated. It is computationally easier than a bivariate continuous distribution and allows for a more flexible distribution if the number of mass points grows large. Moreover, it is common in the literature on labour market transitions; see, for instance, Bover, Arellano and Bentolila (2002), Rebollo (2012), or Bijwaard and Wahba (2014).

Under a discrete frailty distribution, the population consists of several subpopulations with different risks. For instance, one group of more motivated individuals and with a larger social network could have higher probabilities of finding another job but a lower probability to become unemployed or non-employed. The group to which an individual belongs, however, is not observed. The population fractions of the groups are unknown parameters ${ }^{15}$ $p_{k}$. The number of groups is finite and denoted by $K$, with ${ }_{k=1}^{k} p_{k}=1 ; K$ is also the number of mass points of the distribution of $\left(V_{i}^{1}, V_{i}^{2}, V_{i}^{3}\right)$.

We assume that unobserved heterogeneity is constant over time (within and across spells of the same individual). For identification, we also assume it is independent of observed characteristics, the standard assumption in this kind of duration models (Van den Berg, 2001). Moreover, since we do not impose a normalization on the baseline hazard or on $X_{i}(t)^{\prime} \beta^{j}$, we need to impose $E\left(V^{j}\right)=0: \quad p_{k} V^{j}=0$ for $j=1,2,3$ as a normalization.

All parameters are estimated jointly by Maximum Likelihood. The likelihood function is, under the independence assumption, the product of the Likelihood function of all the individuals (i), $L=\prod_{i} L_{i}$. The likelihood contribution $L_{i}$ of individual $i$ for three competing risks $(j=1,2,3)$ can be written as the expected value of the conditional likelihood given $\left(V_{i}^{1}, V_{i}^{2}, V_{i}^{3}\right): L_{i}=\sum_{k=1}^{K} P_{k} \cdot L_{i}\left(V^{k}\right)$, where $L_{i}\left(V^{k}\right)$ is the conditional likelihood contribution given $\left(V_{i}^{1}, V_{i}^{2}, V_{i}^{3}\right)$ is equal to the $k^{\text {th }}$ mass point $V^{k}=\left(V_{k}^{1}, V_{k}^{2}, V_{k}^{3}\right)$. This conditional likelihood

${ }^{15}$ To ensure the probability is between zero and one we assume $p_{k}=\frac{\exp \left(a_{k}\right)}{\left(1+\sum_{l=1}^{K-1} \exp \left(a_{l}\right)\right)}$ 
contribution is a standard likelihood contribution in a model without unobserved heterogeneity; it includes the conditional density function for the observed exits of the completed spells and the conditional survival function for right-censored spells at each competing risks (j):

$$
L_{i}\left(V^{k}\right)=\prod_{j=1}^{3} \prod_{s=1}^{S} h_{s}^{j}\left(t_{i} \mid X_{i}(s), V_{j}^{k}\right)^{d_{i, j, s}} S_{s}^{j}\left(t_{i} \mid X_{i}(s), V_{j}^{k}\right)
$$

Here $s=1, \ldots, s$ are the spells of individual $i$, and $d_{i, j, s}$ is a dummy that is 1 if spell $s$ ends in a transition of type $j$ and 0 otherwise Our Stata code for estimation is largely based upon the Stata code of Bijwaard (2014).

\section{Estimation results}

Job search and matching theory imply that the valuation of labour market states by workers and firms depends on individual and job characteristics, as well as the state of the labour market (Frederiksen and Westergaard-Nielsen, 2007). Moreover, according to more recent models, tenure is explicitly the outcome of the interaction of the dynamics across jobs and workers (Davis and Haltiwanger, 1990, Burgess et al., 1999 and 2001). Empirical studies (Hirsch and Schnabel, 2012; Frederiksen, 2008) also point out the importance of job and individual characteristics. We therefore include them as explanatory variables (see Section 3).

We estimate several specifications of the competing risk models. Table 4 presents the results for our benchmark models. Estimates for alternative specifications are presented in the appendix and briefly discussed below. The best likelihood is obtained using a discrete unobserved heterogeneity distribution with three mass points. ${ }^{16,17}$

\section{Coefficients on the covariates}

One of the most important determinants of job stability is the quarterly regional unemployment rate. Consistent with the descriptive analysis, we find opposite signs: local unemployment is positively correlated with transitions into unemployment, in line with the findings of García-Pérez (1997) and Arranz and García-Serrano (2004) for layoffs, but negatively with exits to other jobs. The latter is in contrast with Blázquez-Cuesta (2008, Table

\footnotetext{
${ }^{16}$ The model with three mass points fits better than the model with two mass points. In the benchmark model the population fraction of the smallest group (5\% and $3 \%$ ) suggests not to grow the number of mass points.

${ }^{17}$ Table A3 in the Appendix shows the results of a competing risks model for exits to other job, unemployment and non-employment in which the three shared frailty terms follow independent Gamma distributions. Comparing to the correlated competing risks model in Table 4 shows that the coefficients retain the same sign and similar size. Significance levels are also similar; only four coefficients change significance level.
} 
A5) who found a positive effect of the yearly unemployment rate coefficient on changing jobs. The effect of the unemployment rate is stronger in exits to unemployment than in switches to other job during the crisis, in line with the higher importance of employment destruction compared to the reduction of job creation during the crisis (Silva and Vázquez-Grenno, 2013).

Coefficients are smaller for the 2009 sample than for 2005, but given the higher unemployment rate, the average elasticity of transitions to unemployment for the regional unemployment rate has increased from 0.23 in 2005 sample to 0.28 in 2009 sample. On the other hand, the elasticity of the job-to-job hazard has changed from -0.23 to -0.14 , maybe because regional mobility has increased during the crisis. Higher regional unemployment reduces exits to non-employment especially in the expansion period.

Gender differences in job stability become smaller during the crisis. The main change is that men in the 2005 sample were much less likely to become unemployed than otherwise similar women, but this advantage shrunk substantially in 2009 (from $24 \%$ to $11 \%$ ). Men are more mobile across jobs, especially in the expansion period ( $8.2 \%$ more than women). During the economic boom, women were more likely (4.6\%) to exit to non-employment, but this difference disappeared in 2009, perhaps because of an added worker effect (fewer women give up their job because their husbands are unemployed or at risk to become unemployed). Previous evidence is mixed: in Blázquez-Cuesta (2008) the male coefficient is not significant in transitions to other job and to non-employment. In Arranz and García-Serrano (2004) and García-Serrano and Malo (1996) men are less likely to become unemployed than their female counterparts, but according to García-Pérez and Muñoz-Bullón (2005) as well as García-Pérez (1997), the gender impact is reversed for longer spell durations.

For both samples, the hazard for other job (except 16-19 aged workers) and nonemployment is negatively correlated with age. This is in line with Blázquez-Cuesta (2008) who finds that transitions to another job or non-employment are more likely among young workers. In general, according with job search and matching theory, older workers have had more time to find a better match that will typically last longer. The job-to-job pattern is consistent with job-shopping (Stigler, 1962). Younger workers are more likely than older ones to try a variety of jobs to learn about the labour market and get a better match. As far as nonemployment exits are concerned, younger workers may not be entitled to unemployment benefits, and those without family responsibilities can more easily emigrate or go back to education than older groups. In contrast, the probability to become unemployed (with 
benefits) increases with age until about age 30 . To sum up, in the downturn, workers of ages 35-55 years become more mobile, while the group of 16-29 years old seems to be hit hardest by the crisis in terms of an increase in the probability of unemployment or non-employment.

Immigrants exhibit more job mobility and fewer transitions to unemployment than natives during the expansion period. The latter may be due to their lower unemployment coverage given their less stable careers. However, in the downturn, the probability of an unemployment exit for Spanish speaking immigrants is similar to that of natives. The job-tojob mobility for both groups of immigrants is reduced, becoming similar to that of natives. Immigrants show more transitions to non-employment than natives in both periods, probably due to return migration (Dustmann et al., 2010). In conclusion, specifically Spanish speaking immigrants have suffered the largest fall in job stability in the contraction period.

There is no clear pattern in the effects of having dependent children on the hazards, with changing signs and significance levels. In both periods, individuals living in larger cities show lower job mobility and a lower exit probability to non-employment, but they are more likely to enter unemployment than others.

A higher level of education reduces the probability to become unemployed in both periods. The difference between primary and lower secondary education is significant during the crisis only. This is in line with the theory predicting that during the crisis, firms fire the more replaceable low educated employees. On the other hand, the higher educated have a higher probability to exit to non-employment in both periods. During the crisis, job mobility is rising with education level. This may reveal a preference on the firm side for recruiting higher educated workers. To conclude, it seems that the least educated workers are the most adversely affected by the economic crisis, both in terms of job-to-job mobility and in the chances of unemployment.

Workers in non-manual occupations have more stable jobs than manual workers, with lower hazards in both periods for all destinations, particularly to unemployment. Arranz and García-Serrano (2004) found that non-manual workers have a lower probability of job termination than manual workers due to temporary contracts. 
Table 4: Estimation results of correlated competing risks (exit to other job, unemployment and non-employment) models for 2005 and 2009 samples

\begin{tabular}{|c|c|c|c|c|c|c|}
\hline & \multicolumn{3}{|c|}{2005} & \multicolumn{3}{|c|}{2009} \\
\hline & Job & Unemp. & Non- & Job & Unemp. & Non-emp. \\
\hline Unemployment rate & $\begin{array}{c}-2.304^{* * *} \\
(0.148)\end{array}$ & $\begin{array}{c}2.285^{* * *} \\
(0.165)\end{array}$ & $\begin{array}{c}-0.331 * * * \\
(0.125)\end{array}$ & $\begin{array}{c}-0.679 * * * \\
(0.124)\end{array}$ & $\begin{array}{l}1.388 * * * \\
(0.0842)\end{array}$ & $(0.0942)$ \\
\hline Male & $\begin{array}{c}0.0784 * * * \\
(0.0120)\end{array}$ & $\begin{array}{c}-0.271 * * * \\
(0.0155)\end{array}$ & $\begin{array}{c}-0.0473 * * * \\
(0.0110)\end{array}$ & $\begin{array}{c}0.0525^{* * *} \\
(0.0142)\end{array}$ & $\begin{array}{c}-0.114 * * * \\
(0.0104)\end{array}$ & $\begin{array}{c}0.0113 \\
(0.0107)\end{array}$ \\
\hline Aged_16_19 & $\begin{array}{c}-0.342 * * * \\
(0.0262)\end{array}$ & $\begin{array}{c}-1.081 * * * \\
(0.0522)\end{array}$ & $\begin{array}{c}0.834 * * * \\
(0.0170)\end{array}$ & $\begin{array}{c}-0.519 * * * \\
(0.0552)\end{array}$ & $\begin{array}{c}-0.860 * * * \\
(0.0483)\end{array}$ & $\begin{array}{c}0.915^{* * *} \\
(0.0229)\end{array}$ \\
\hline Aged_20_24 & $\begin{array}{c}-0.0527 * * * \\
(0.0130)\end{array}$ & $\begin{array}{c}-0.239 * * * \\
(0.0192)\end{array}$ & $\begin{array}{l}0.414 * * * \\
(0.0120)\end{array}$ & $\begin{array}{c}-0.130 * * * \\
(0.0212)\end{array}$ & $\begin{array}{c}-0.149 * * * \\
(0.0166)\end{array}$ & $\begin{array}{c}0.454 * * * \\
(0.0147)\end{array}$ \\
\hline Aged_30_34 & $\begin{array}{c}-0.0664 * * * \\
(0.0127)\end{array}$ & $\begin{array}{c}0.0901 * * * \\
(0.0171)\end{array}$ & $\begin{array}{c}-0.139 * * * \\
(0.0137)\end{array}$ & $\begin{array}{c}-0.0611 * * * \\
(0.0189)\end{array}$ & $\begin{array}{c}0.0399 * * * \\
(0.0141)\end{array}$ & $\begin{array}{c}-0.174 * * * \\
(0.0159)\end{array}$ \\
\hline Aged_35_39 & $\begin{array}{c}-0.158 * * * \\
(0.0150)\end{array}$ & $\begin{array}{c}0.0912^{* * *} \\
(0.0189)\end{array}$ & $\begin{array}{c}-0.152 * * * \\
(0.0157)\end{array}$ & $\begin{array}{c}-0.120 * * * \\
(0.0209)\end{array}$ & $\begin{array}{c}0.0567^{* * *} \\
(0.0150)\end{array}$ & $\begin{array}{c}-0.192 * * * \\
(0.0177)\end{array}$ \\
\hline Aged_40_44 & $\begin{array}{c}-0.228 * * * \\
(0.0169)\end{array}$ & $\begin{array}{c}0.0831^{* * *} \\
(0.0203)\end{array}$ & $\begin{array}{c}-0.150 * * * \\
(0.0172)\end{array}$ & $\begin{array}{c}-0.158^{* * *} \\
(0.0233)\end{array}$ & $\begin{array}{c}0.0853 * * * \\
(0.0160)\end{array}$ & $\begin{array}{c}-0.209 * * * \\
(0.0193)\end{array}$ \\
\hline Aged_45_49 & $\begin{array}{c}-0.334 * * * \\
(0.0190)\end{array}$ & $\begin{array}{c}0.0632^{* * *} \\
(0.0216)\end{array}$ & $\begin{array}{c}-0.249 * * * \\
(0.0192)\end{array}$ & $\begin{array}{c}-0.204 * * * \\
(0.0257)\end{array}$ & $\begin{array}{c}0.0969 * * * \\
(0.0167)\end{array}$ & $\begin{array}{r}-0.242^{\prime} \\
(0.021\end{array}$ \\
\hline Aged_50_55 & $\begin{array}{c}-0.460 * * * \\
(0.0247)\end{array}$ & $\begin{array}{c}0.118 * * * \\
(0.0254)\end{array}$ & $\begin{array}{c}-0.237 * * * \\
(0.0240)\end{array}$ & $\begin{array}{c}-0.312 * * * \\
(0.0315)\end{array}$ & $\begin{array}{c}0.101 * * * \\
(0.0192)\end{array}$ & $\begin{array}{c}-0.245^{* * *} \\
(0.0250)\end{array}$ \\
\hline $\begin{array}{l}\text { Spanish speakers } \\
\text { immigrants }\end{array}$ & $\begin{array}{l}0.157^{* * *} \\
(0.0191)\end{array}$ & $\begin{array}{c}-0.328^{* * *} \\
(0.0305)\end{array}$ & $\begin{array}{l}0.299 * * * \\
(0.0189)\end{array}$ & $\begin{array}{l}-0.00910 \\
(0.0283)\end{array}$ & $\begin{array}{c}0.0139 \\
(0.0196)\end{array}$ & $\begin{array}{l}0.308 * * * \\
(0.0206)\end{array}$ \\
\hline $\begin{array}{l}\text { Non Spanish speakers } \\
\text { immigrants }\end{array}$ & $\begin{array}{c}0.0665^{* * *} \\
(0.0185)\end{array}$ & $\begin{array}{l}-0.113^{* * *} \\
(0.0261)\end{array}$ & $\begin{array}{l}0.323^{* * *} \\
(0.0180)\end{array}$ & $\begin{array}{c}0.0262 \\
(0.0213)\end{array}$ & $\begin{array}{c}-0.117^{* * *} \\
(0.0151)\end{array}$ & $\begin{array}{l}0.305 * * * \\
(0.0157)\end{array}$ \\
\hline Children_4 & $\begin{array}{l}-0.0254^{*} \\
(0.0135)\end{array}$ & $\begin{array}{c}0.0834 * * * \\
(0.0169)\end{array}$ & $\begin{array}{l}-0.00763 \\
(0.0138)\end{array}$ & $\begin{array}{l}-0.0321 * \\
(0.0190)\end{array}$ & $\begin{array}{l}0.0762^{* * *} \\
(0.0129)\end{array}$ & $\begin{array}{c}-0.0748^{* * *} \\
(0.0157)\end{array}$ \\
\hline Children_15 & $\begin{array}{l}-0.00938 \\
(0.0119)\end{array}$ & $\begin{array}{c}0.0357^{* * *} \\
(0.0138)\end{array}$ & $\begin{array}{c}-0.0643 * * * \\
(0.0122)\end{array}$ & $\begin{array}{l}0.0316^{*} \\
(0.0163)\end{array}$ & $\begin{array}{l}0.0544^{* * *} \\
(0.0106)\end{array}$ & $\begin{array}{c}-0.112 * * * \\
(0.0138)\end{array}$ \\
\hline Primary_education & $\begin{array}{l}-0.0205^{*} \\
(0.0121)\end{array}$ & $\begin{array}{l}0.0268^{*} \\
(0.0146)\end{array}$ & $\begin{array}{l}0.0971 * * * \\
(0.0116)\end{array}$ & $\begin{array}{c}-0.0456^{* *} \\
(0.0184)\end{array}$ & $\begin{array}{l}0.0906 * * * \\
(0.0113)\end{array}$ & (0.0136) \\
\hline Upper secondary & $(0.0115)$ & $\begin{array}{c}-0.144 * * * \\
(0.0148)\end{array}$ & $\begin{array}{l}0.105^{* * *} \\
(0.0110)\end{array}$ & $\begin{array}{c}0.0126 \\
(0.0166)\end{array}$ & $\begin{array}{c}-0.142 * * * \\
(0.0119)\end{array}$ & $\begin{array}{l}0.125^{* * *} \\
(0.0127)\end{array}$ \\
\hline Post-secondary & $\begin{array}{c}0.0113 \\
(0.0147)\end{array}$ & $\begin{array}{l}-0.486 * * * \\
(0.0214)\end{array}$ & $\begin{array}{l}0.211^{* * *} \\
(0.0134)\end{array}$ & $\begin{array}{l}0.0431^{* *} \\
(0.0206)\end{array}$ & $\begin{array}{c}-0.470 * * * \\
(0.0170)\end{array}$ & $\begin{array}{c}0.143^{* * *} \\
(0.0156)\end{array}$ \\
\hline Inhabitants> & $\begin{array}{c}-0.0369 * * * \\
(0.00875)\end{array}$ & $\begin{array}{c}0.0241 * * \\
(0.0112)\end{array}$ & $\begin{array}{c}-0.0703 * * * \\
(0.00843)\end{array}$ & $\begin{array}{c}-0.0571 * * * \\
(0.0128)\end{array}$ & $\begin{array}{c}0.0173 * \\
(0.00892)\end{array}$ & $\begin{array}{c}-0.0435^{* * *} \\
(0.00982)\end{array}$ \\
\hline Non manual & $\begin{array}{c}-0.0623 * * * \\
(0.0113)\end{array}$ & $\begin{array}{c}-0.256^{* * *} \\
(0.0145)\end{array}$ & $\begin{array}{c}-0.200 * * * \\
(0.0103)\end{array}$ & $\begin{array}{l}-0.0309 * \\
(0.0159)\end{array}$ & $\begin{array}{c}-0.300 * * * \\
(0.0116)\end{array}$ & $\begin{array}{c}-0.106 * * * \\
(0.0117)\end{array}$ \\
\hline Construction & $\begin{array}{c}-0.0552 * * * \\
(0.0125)\end{array}$ & $\begin{array}{c}-0.338^{* * *} \\
(0.0177)\end{array}$ & $\begin{array}{c}-0.316 * * * \\
(0.0133)\end{array}$ & $\begin{array}{c}-0.138 * * * \\
(0.0202)\end{array}$ & $\begin{array}{c}0.202 * * * \\
(0.0132)\end{array}$ & $\begin{array}{c}-0.241 * * * \\
(0.0170)\end{array}$ \\
\hline M & $\begin{array}{c}-0.324 * * * \\
(0.0161)\end{array}$ & $\begin{array}{r}-0.00685 \\
(0.0183)\end{array}$ & $\begin{array}{c}-0.274 * * * \\
(0.0157)\end{array}$ & $\begin{array}{c}-0.250 * * * \\
(0.0261)\end{array}$ & $\begin{array}{l}0.00698 \\
(0.0166)\end{array}$ & $\begin{array}{c}-0.240 * * * \\
(0.0217)\end{array}$ \\
\hline
\end{tabular}


Table 4, continued

\begin{tabular}{|c|c|c|c|c|c|c|}
\hline & & & & & & \\
\hline & Job & Unemp. & Non-emp. & Job & Unemp. & Non-emp. \\
\hline \multirow[t]{2}{*}{ High_technology } & $0.0790 * * *$ & $-0.122 * * *$ & $-0.0700 * * *$ & $0.0608^{*}$ & $-0.0653^{* *}$ & $-0.135 * * *$ \\
\hline & $(0.0165)$ & $(0.0228)$ & $(0.0166)$ & $(0.0357)$ & $(0.0296)$ & $(0.0336)$ \\
\hline \multirow[t]{2}{*}{ Dummy missing firm size } & $0.941 * * *$ & $0.436 * * *$ & $0.438 * * *$ & $0.951 * * *$ & $0.601 * * *$ & $0.562 * * *$ \\
\hline & $(0.0173)$ & $(0.0269)$ & $(0.0182)$ & (0.0309) & $(0.0237)$ & $(0.0236)$ \\
\hline \multirow[t]{2}{*}{ Size_10_19 } & $-0.0538 * * *$ & $-0.156^{* * *}$ & $-0.0826 * * *$ & $-0.105^{* * *}$ & $-0.177^{* * *}$ & $-0.119 * * *$ \\
\hline & $(0.0145)$ & (0.0189) & $(0.0143)$ & $(0.0210)$ & $(0.0146)$ & $(0.0168)$ \\
\hline \multirow[t]{2}{*}{ Size_20_49 } & $-0.116 * * *$ & $-0.249 * * *$ & $-0.124 * * *$ & $-0.175 * * *$ & $-0.224 * * *$ & $-0.143 * * *$ \\
\hline & $(0.0135)$ & $(0.0175)$ & $(0.0133)$ & $(0.0198)$ & $(0.0138)$ & $(0.0156)$ \\
\hline \multirow[t]{2}{*}{ Size_50_249 } & $-0.250 * * *$ & $-0.256 * * *$ & $-0.127^{* * *}$ & $-0.330 * * *$ & $-0.296 * * *$ & $-0.177 * * *$ \\
\hline & $(0.0132)$ & $(0.0164)$ & $(0.0124)$ & (0.0189) & $(0.0130)$ & $(0.0143)$ \\
\hline \multirow[t]{2}{*}{ size_250 } & $-0.386 * * *$ & $-0.357 * * *$ & $-0.123 * * *$ & $-0.539 * * *$ & $-0.389 * * *$ & $-0.233 * * *$ \\
\hline & $(0.0150)$ & $(0.0188)$ & $(0.0136)$ & $(0.0217)$ & $(0.0152)$ & $(0.0160)$ \\
\hline \multirow[t]{2}{*}{ Open-ended } & $-0.886 * * *$ & $0.723 * * *$ & $-0.321 * * *$ & $-0.878 * * *$ & $0.314^{* * *}$ & $-0.313 * * *$ \\
\hline & $(0.0387)$ & $(0.0214)$ & $(0.0253)$ & $(0.0417)$ & $(0.0166)$ & $(0.0228)$ \\
\hline \multirow[t]{2}{*}{ Permanent } & $-1.434 * * *$ & $-2.089 * * *$ & $-1.980 * * *$ & $-1.163 * * *$ & $-1.775^{* * *}$ & $-1.816 * * *$ \\
\hline & $(0.0130)$ & $(0.0222)$ & $(0.0152)$ & $(0.0177)$ & $(0.0151)$ & $(0.0172)$ \\
\hline \multirow[t]{2}{*}{ On-call Temporary } & $-0.126 * * *$ & $-0.301 * * *$ & $0.0730 * * *$ & 0.0198 & $-0.154^{* * *}$ & $0.214^{* * *}$ \\
\hline & $(0.0224)$ & $(0.0252)$ & $(0.0192)$ & $(0.0267)$ & $(0.0195)$ & $(0.0198)$ \\
\hline \multirow[t]{2}{*}{ Temporary Agency } & $1.082 * * *$ & $0.168 * * *$ & $0.359 * * *$ & $1.110 * * *$ & $0.233^{* * *}$ & $0.368 * * *$ \\
\hline & $(0.0182)$ & $(0.0306)$ & $(0.0185)$ & $(0.0285)$ & $(0.0260)$ & $(0.0239)$ \\
\hline \multirow[t]{2}{*}{ Public Sector } & $-0.532 * * *$ & $0.198 * * *$ & -0.0185 & $-0.282 * * *$ & $0.158 * * *$ & -0.0181 \\
\hline & $(0.0228)$ & $(0.0217)$ & $(0.0175)$ & $(0.0260)$ & $(0.0165)$ & $(0.0178)$ \\
\hline \multirow[t]{2}{*}{ In_daily_salary } & $0.175^{* * *}$ & $0.144 * * *$ & $-0.231 * * *$ & $0.237 * * *$ & $0.0570 * * *$ & $-0.145 * * *$ \\
\hline & $(0.0124)$ & $(0.0155)$ & $(0.0114)$ & $(0.0166)$ & $(0.0119)$ & $(0.0122)$ \\
\hline \multirow[t]{2}{*}{ Part time coef. } & $0.142 * * *$ & $0.733 * * *$ & $-0.596 * * *$ & $-0.135 * * *$ & $0.563 * * *$ & $-0.720 * * *$ \\
\hline & $(0.0298)$ & $(0.0382)$ & $(0.0241)$ & $(0.0380)$ & $(0.0279)$ & $(0.0261)$ \\
\hline \multirow[t]{2}{*}{ V1 } & $-0.590 * * *$ & $-0.134 * *$ & $0.706 * * *$ & $-0.461 * * *$ & $0.0558^{* *}$ & $0.942 * * *$ \\
\hline & $(0.0931)$ & $(0.0581)$ & $(0.0464)$ & $(0.101)$ & $(0.0277)$ & $(0.00988)$ \\
\hline \multirow[t]{2}{*}{ V2 } & $0.394 * * *$ & $0.158 * * *$ & $-0.125^{* * *}$ & $0.716^{* * *}$ & $0.0915^{* * *}$ & $0.106^{* * *}$ \\
\hline & $(0.0269)$ & $(0.0236)$ & $(0.0372)$ & $(0.0727)$ & $(0.0342)$ & $(0.0212)$ \\
\hline \multirow[t]{2}{*}{ a1 } & $1.779 * * *$ & & & $2.918^{* * *}$ & & \\
\hline & $(0.181)$ & & & $(0.134)$ & & \\
\hline \multirow[t]{2}{*}{ a2 } & $2.477 * * *$ & & & $2.592 * * *$ & & \\
\hline & $(0.161)$ & & & $(0.220)$ & & \\
\hline Observations & 903,147 & 903,147 & 903,147 & 715,705 & 715,705 & 715,705 \\
\hline Log Likelihood & $-1,303,000$ & & & $-1,049,000$ & & \\
\hline Number of ids & 176,419 & 176,419 & 176,419 & 141,153 & 141,153 & 141,153 \\
\hline Number of exits & 63,314 & 35,476 & 73,016 & 29,627 & 57,825 & 51,015 \\
\hline Terms of mass points & 1 & 2 & 3 & 1 & 2 & 3 \\
\hline Probability & 0.31 & 0.63 & 0.05 & 0.56 & 0.41 & 0.03 \\
\hline V job & -0.59 & 0.39 & -1.19 & -0.46 & 0.72 & -1.03 \\
\hline V unemployment & -0.13 & 0.16 & -1.09 & 0.06 & 0.09 & -2.25 \\
\hline \multirow{2}{*}{ V non-employment } & 0.71 & -0.12 & -2.69 & 0.941 & 0.11 & -18.83 \\
\hline & Unemployment & Non-emp. & & Unemployment & Non-emp. & \\
\hline Job & 0.86 & 0.02 & & 0.35 & 0.31 & \\
\hline Unemployment & & 0.53 & & & 0.96 & \\
\hline
\end{tabular}

Notes: Piecewise baseline and discrete distribution of unobserved heterogeneity with three mass points. References categories: female, Aged_25_29, lower secondary education level, Native Spanish, manual occupation, services sector,non-high technology sector, size_1_9, temporary contract, Private sector. Age, daily wage, and quarterly unemployment rate are time-varying variables. Significance levels: ${ }^{* *} p<0.01$, ${ }^{* *} p<0.05, * p<0.1$. There was a convergence problem in the estimation of the model for 2009 sample. The baseline hazard and the unobserved heterogeneity terms (V1 and V2) for exits to non-employment were not significant (huge SE). Then, we estimated again the model but fixing V1 and V2 (for non-employment) to their previous estimated values, and the baseline hazard for non-employment became significant (same values as before but with reasonable SE). Lastly, we fixed everything to their estimated values other than V1 and V2 for non-employment, and then we also found the SE for those unobserved heterogeneity terms. 
The relation between industry and job duration varies over the business cycle and destination states. The results show that different industries are affected differently by the crisis. For example, the burst of the housing bubble severely hit the construction sector so that workers in construction suffered a substantial increase in the probability to become unemployed, going from the lowest to the highest unemployment exit probability, and a fall in job-to-job rotation. Jobs in sectors more intensive technology where human capital accumulation is more relevant, seem to be more stable than those in other sectors, showing lower incidence in unemployment and non-employment, but higher job mobility in both periods.

The estimated coefficients on firm size all confirm that job stability increases with firm size. This is in line with the findings of Blázquez-Cuesta (2008) for the period 19952001. During the crisis, the probability of job exit to any destination state has decreased compared to the reference category (firm size 1-9). Especially workers in the largest firms exhibit a decline in all the hazard rates compared to those in the smallest firms, particularly in transitions to other jobs and non-employment. Firms for which firm size is missing are often unstable firms that have disappeared, explaining why exit rates in these firms are higher, particularly during the downturn. Larger firms tend to provide better working conditions, implying higher separation costs for employers and higher opportunity cost of quitting. Larger investment in the hiring process ensures a better matching between employee and employer. In contrast, small firms usually offer shortterm jobs due to a lower capability of internal labour market adjustments.

Public sector workers are less likely to change jobs but more likely to become unemployed than those in the private sector. Previous evidence on this is mixed: GarcíaPérez and Muñoz-Bullón (2005) find a positive impact of public sector on the hazard from employment to unemployment, not including job characteristics such as type of contract, firm size or industry. Blázquez-Cuesta (2008) finds that working in the public sector reduces the hazard of changing jobs. 
Following Blázquez-Cuesta $(2008)^{18}$ we also consider the wage level as a job characteristic (taken as exogenous). The influence of the wage level ${ }^{19}$ on the separation rates differs across economic periods. Workers with higher wages exhibit higher job mobility (especially in the downturn), more chances to become unemployed (mainly during the expansion period), and lower separation rates to non-employment. In contrast to our results, Arranz and García-Serrano (2004) found a disincentive effect of wages on the hazard rate for involuntary job termination (layoff and end of temporary contract) for the period 1987-1997; they did not include characteristics of the current job such as type of contract, industry, firm size and part time coefficient. The positive relationship between earnings and the hazard of unemployment in the expansion period might be explained by the strategic use of unemployment benefits by firms and workers with consecutive employment spells and unemployment benefit spells (Alba et al., 2012). In the downturn this seems to be less relevant.

Job starters with a higher part-time coefficient have higher job mobility and unemployment risk, especially in 2005 , but a lower probability to exit into nonemployment.

\section{Unobserved heterogeneity}

In the competing risks estimations, unobserved heterogeneity is significant in both periods, demonstrating the importance of unobserved characteristics such as motivation, effort, social pressure, etc. for the chances to remain in the same job. According to the estimated discrete distribution, the correlation between the unobserved heterogeneity terms changes over the business cycle. The most interesting one is the significant correlation between job-to-job and unemployment hazards, which is 0.86 in 2005 and 0.35 in 2009. This implies that someone who is likely to become unemployed also has higher chances of exiting to another job, particularly during the

\footnotetext{
${ }^{18}$ Blázquez-Cuesta (2008) demonstrates that low pay can be assumed to be exogenous to job mobility.

${ }^{19}$ Since in the LWLS information about hours worked is not available we cannot compute hourly wages. The possible distortion, already mentioned by Arranz and García-Serrano (2012), due to using daily wage instead of hourly wage is mitigated by the small proportion of part-time jobs and the inclusion of the parttime coefficient as an explanatory variable.
} 
expansion period. This could point at the strategic use of unemployment benefits during the expansion period.

\section{Baseline Hazards}

Figure 3 shows the survival and hazard functions of the competing risks model for a benchmarck person. Unlike Figures 1 and 2, observed and unobserved heterogeneity are controlled for through the covariates and frailty terms, so that slopes can be interpreted as true state dependence. The top panel shows, for instance, that in the benchmarck group in 2005, 43\% would move to another job within 1 year, 21\% would become unemployed and $41 \%$ non-employed, so that the probability of ending the current job would be $73 \%((1-0.56 * 0.78 * 0.59) * 100)$. In 2009 , the probability to switch to another job has fallen by $11 \%$ points, while the probability to become unemployed has increased by $18 \%$ points and the likelihood to become non-employed has slightly fallen. Adding up these three, the bechmarck group's probability to ending the job remains virtually constant, in line with the flat separation pattern over the business cycle found by Bachman (2005). Correspondingly, while the overall median job duration (not shown) was approximately seven months in both periods, the median job durations (assuming other competing risks do not exist) for exits to other jobs increased from 14 to 19 months and for non-employment from 16 to 19 months, while it decreased from 25 to 15 months for unemployment transitions.

The bottom panel shows the corresponding hazard rates. During the expansion, exits to other jobs are generally more likely than to unemployment, while the opposite is found in the downturn. This confirms that hazard rates into unemployment are countercyclical while hazard rates for job-to-job exits or into non-employment are procyclical, resulting in an almost constant overall hazard over the business cycle.

Among previous Spanish evidence, García-Perez and Muñoz-Bullón (2005) found that the hazard into unemployment is counter-cyclical only for short employment spells (under 5 months) and García-Pérez (1997), for the period 1978-1993, found weakly procyclical pattern for short jobs and a-cyclical patterns for jobs longer than six months. The international evidence, however, reveals strong counter-cyclicality. 
Figure 3: Survival functions (top panel) and hazard rates (bottom panel) benchmark person for job, unemployment and non-employment transitions; 2005 and 2009 samples; competing risks model
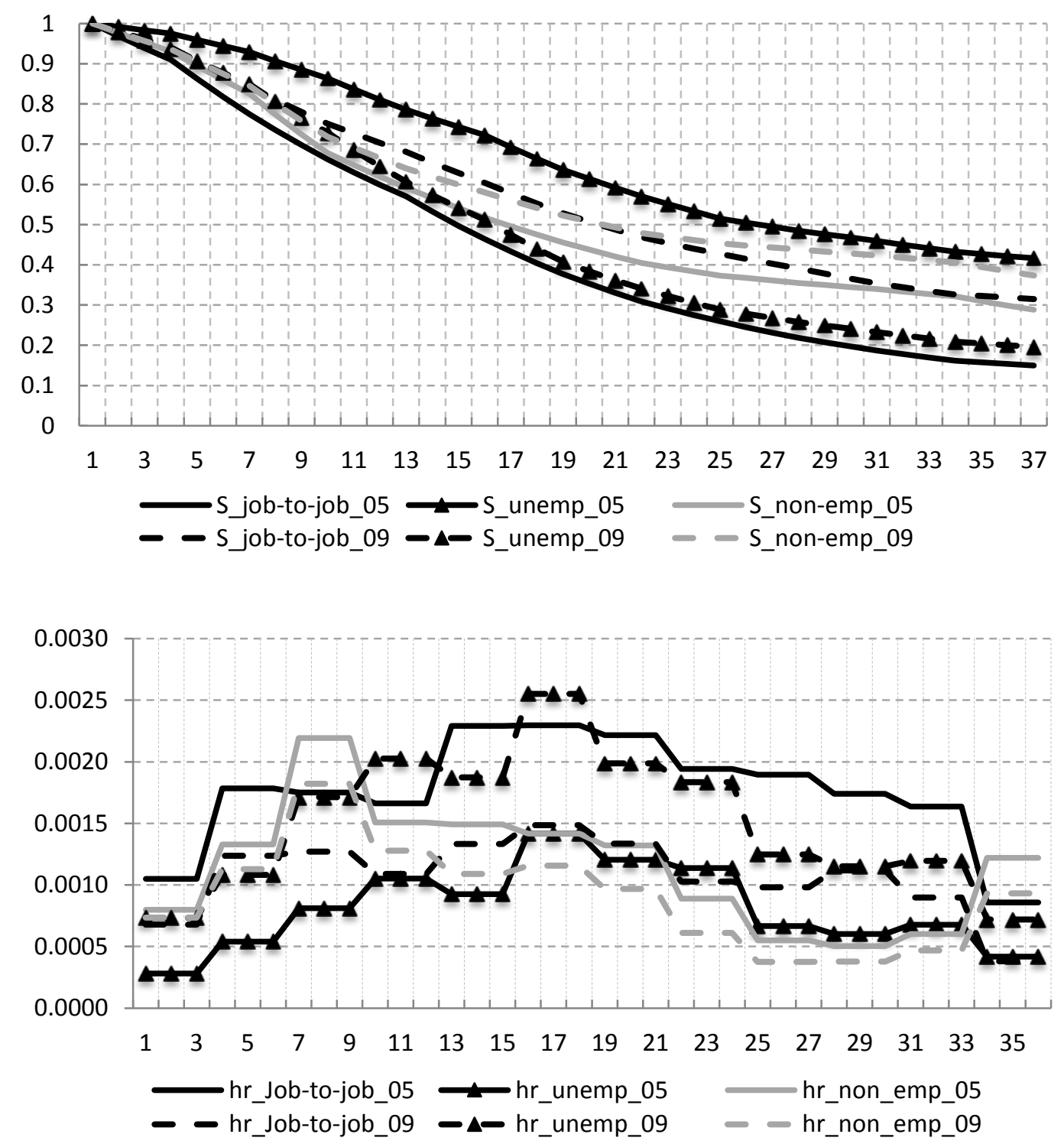

Note: Benchmarck individual: male, low-skilled, non-manual occupation, native, 25-29 Aged, No children, services sector, Non-High-Technology, temporary contract, firm size 1-9, No through Temporary Help Agency, private sector. For continuous variables mean value is taken.

For exits to other job and unemployment, we find positive duration dependence during the first 1.5 years of employment (stronger in exits to unemployment in 2009 and in transitions to other job in 2005), that subsequently turns negative. These patterns might be explained by job matching theory. In a first stage hazard rates increase since employers and employees are learning from the matching quality; thereafter job exits decline and good matches survive. Since job-to-job exits dominate in 2005 and job-to- 
unemployment exits in 2009 , the job separation process is more an employee decision in 2005 (given that in the expansion period workers have more chances to leave poor matches), while in 2009 job separations are more driven by employer decisions and workers are willing to remain in a poor match due to the lack of job oportunities. The initially increasing pattern of the job-to-unemployment hazard may also be explained by the lower number of workers entitled to unemployment benefits ${ }^{20}$ after a few days of contribution.

\subsection{The role of compositional variation and business cycle in job duration}

Table 5 shows the results of decompositions of the difference between the survival probabilities after 360 days in the periods before and during the crisis, in the spirit of, for example, Verho (2014). The first rows give the average survival probabilities for the two samples according to the model estimates ${ }^{21}$ and the difference between these two. For example, according to the competing risk model the average probability of not switching to another job (assuming no other exit possibilities) was 71.76 percent, which increased to 80.44 percent in the 2009 sample, a difference of 8.69 percentage points. In the same line, the average of not exiting to non-employment increased from 61.76 percent in 2005 to 72.6 percent in 2009. In contrast, the probability of not becoming unemployed decreased substantially from 83.8 percent in 2005 sample to 66.38 percent in 2009 sample.

The remaining rows show the decomposition of these differences. First, we take the 2005 estimates and the 2005 regional unemployment rates, but compute the average probabilities for the new job starters in the 2009 sample. Comparing with the 2005 probabilities in row 3 gives the composition effect: the difference explained by the fact that individual and job characteristics in the 2009 and 2005 samples are different.

Despite the significant changes in the sample characteristics examined in section 4, the composition effect explains partially the substantial changes in transitions to

\footnotetext{
${ }^{20}$ The minimum contributory period required to be entitled to the unemployment insurance benefit is 12 months in the last 6 years. For the means tested assistance benefits, it is 3 (with family responsibilities) or 6 months in the last 6 years for individuals without family responsibilities.

${ }^{21}$ Here for simplicity the time-varying variables are considered constant over time. We use the age and the daily wage at the moment of starting the new job. And the average regional unemployment rate in the period considered by gender.
} 
other jobs and to unemployment, only about 6 percent of the differences. In contrast, sample composition differences explain almost half of the total differences in nonemployment.

Table 5: Decomposition analysis for exits from the current job to other job, unemployment and non-employment

\begin{tabular}{|c|c|c|c|c|c|c|}
\hline \multirow[b]{2}{*}{ Total Effect } & \multicolumn{2}{|c|}{ Other job } & \multicolumn{2}{|c|}{ Unemployment } & \multicolumn{2}{|c|}{ Non-employment } \\
\hline & $8.69 \%$ & $100 \%$ & $-17.51 \%$ & $100 \%$ & $10.91 \%$ & $100 \%$ \\
\hline$\overline{S_{09,09}^{09}}$ & $80.44 \%$ & & $66.38 \%$ & & $72.67 \%$ & \\
\hline$S_{05,05}^{05}$ & $71.76 \%$ & & $83.89 \%$ & & $61.76 \%$ & \\
\hline Composition effects & $0.56 \%$ & $6 \%$ & $-1.31 \%$ & $7 \%$ & $5.22 \%$ & $48 \%$ \\
\hline Business cycle effects & $8.12 \%$ & $94 \%$ & $-16.20 \%$ & $93 \%$ & $5.69 \%$ & $52 \%$ \\
\hline
\end{tabular}

\section{Conclusions}

We have analysed the nature of new job matches in Spain starting before (2005) and during the recent recession (2009). Job exits were explored for an observation window of three years, distinguishing several destination states.

The data reveal substantial variation over the business cycle in the characteristics of both workers and jobs in new matches, due to both supply and demand factors. For example, during the recession, the workers in new matches are more experienced and are more often non-Spanish speaking immigrants. The crisis leads to a fall of construction and manufacturing jobs, also implying a reduction of new matches for male workers, overrepresented in these sectors.

Our results on job exit rates in the two periods show two opposing forces that cancel out: the pro-cyclicality of job-to-job and job-to-non-employment (including unemployment without benefits) transitions, and the counter-cyclical nature of exits into unemployment (with benefits). Exits to other jobs and to non-employment (typically supply driven), are more likely than exits to unemployment (demand driven) in a period of economic growth. The opposite is true in the downturn. 
A decomposition analysis shows that changing characteristics of the pool of new job starters explain virtually nothing of the substantial changes of exits to other jobs or unemployment. Most of the variation is due to business cycle effects, applying to individuals with given characteristics and job attributes. On the other hand, changes in average survival probabilities of non-employment are explained by sample composition and business cycle effects to approximately the same extent.

A limitation of the current study is that neither the quality of a match nor the job options at the time of separation are directly observed. Both depend on the business cycle and influence job duration. For instance, we cannot determine whether the reduction in the hazard of exits to other jobs in the recession period is due to better matching or to a scarcity of job offers that make individuals hang on to their jobs even if the match is rather poor.

Job exits to unemployment are the most worrying issue for policy purposes, because of their implications for the unemployment rate, welfare, human capital accumulation, and social and health problems. ${ }^{22}$ Workers in new job matches are particularly vulnerable to becoming unemployed during the crisis. The individuals hit hardest by the crisis are males and young workers (16-29), lower educated workers, Spanish speaking migrants, and workers in manual occupations and the construction sector. A labour market policy of providing low quality and temporary jobs would not be effective for these groups, who seem to be trapped in inferior and unstable jobs. It seems better to create facilities for productivity enhancing (on the job) training, ${ }^{23}$ together with specific social protection measures.

The decline in job-to-job transitions during the downturn may reduce labour market efficiency and productivity growth (Lentz and Mortensen, 2005; Hyatt and McEntarfer, 2012) and may affect working conditions improvements. Workers with reduced job-to-job mobility in the recession period are males and immigrants, the youngest age groups, workers with low education level or manual occupations. Finally,

\footnotetext{
${ }^{22}$ According to Silva and Vázquez-Grenno (2013), the contributions of the employment-unemployment hazard is much more important than that of the job finding rate in explaining fluctuations in Spain's macro unemployment rate. Transitions from unemployment to employment before and during the crisis are analyzed in Nagore and van Soest (2014).

${ }^{23}$ Dual programs are already provided to the unemployed, combining employment and training in a training center (Royal Decree 1529/2012, of 9 November).
} 
those showing an increase in the likelihood to become non-employed are males and young workers (16-29), Spanish speaking immigrants, those working in non-manual occupations, individuals without family responsibilities and workers in the construction sector.

The proportion of workers starting a new job in large firms in 2009 is slightly lower than in 2005. New job starters have more stable jobs in larger firms, especially during the downturn. This result sheds light upon the current policy debate of the necessity of stimulating firm growth in Spain, to increase productivity and employment stability, in line with the Europe 2020 strategy of sustainable growth. Policy should not only focus on creating new (small) firms but also on letting these firms grow and stabilize.

In line with this, current policy proposals aim at boosting firms to enter into new emerging sectors. Our results show that during the crisis fewer new hires were realized in high technology firms, while these new jobs appear more stable than those starting in the non-intensive technology sector during both economic periods. In a sector intensive in knowledge, human capital accumulation is crucial and should lead to enhanced job stability. 


\section{Appendix A}

\section{Table A1: Definitions of explanatory variables}

Individual characteristics

\begin{tabular}{|c|c|}
\hline Male & 1 if male \\
\hline $\begin{array}{l}\text { Age at the moment of } \\
\text { exiting the current job }\end{array}$ & $16-19 ; 20-24 ; 25-29 ; 30-34 ; 35-39 ; 40-44 ; 45-49 ; 50-55$. It is a time varying covariate \\
\hline Spanish native & 1 if Spanish citizenship \\
\hline $\begin{array}{l}\text { Spanish-speaking } \\
\text { immigrants }\end{array}$ & 1 if immigrant comes from a Spanish-speaking country \\
\hline $\begin{array}{l}\text { Non-Spanish speaking } \\
\text { immigrants }\end{array}$ & 1 if immigrant comes from a non-Spanish-speaking country \\
\hline Dummy children_4 & 1 if the individual has children younger than 4 years old. It is a time-varying covariate \\
\hline Dummy children_15 & $\begin{array}{l}1 \text { if the individual has children between } 4 \text { and } 15 \text { years old. It is a time-varying } \\
\text { covariate }\end{array}$ \\
\hline Primary education & 1 if none and elementary education level \\
\hline Lower secondary & 1 if lower secondary education level (middle school) \\
\hline Upper secondary & 1 if upper secondary education level (high school) \\
\hline Post-secondary & 1 if tertiary education level \\
\hline \multicolumn{2}{|r|}{ Macroeconomic variables } \\
\hline Unemployment rate & $\begin{array}{l}\text { Quarterly unemployment rate by gender and region of residence (time-varying); } \\
\text { source: Economically Active Population Survey (EPA). Time varying covariate }\end{array}$ \\
\hline Inhabitants $>40,000$ & $\begin{array}{l}1 \text { if the number of inhabitants of the municipality where the individual is living is } \\
\text { greater than } 40.000 \text {. Time-varying covariate }\end{array}$ \\
\hline \multicolumn{2}{|r|}{ Current job spell variables } \\
\hline Non-manual occupation & 1 if non-manual occupation \\
\hline Sector of activity & Manufacturing, construction and services \\
\hline High Technology & $\begin{array}{l}1 \text { if sector of activity in high technology according with the classification of industries } \\
\text { by technologic level }\end{array}$ \\
\hline Type of contract & Permanent, on-call temporary, temporary, open-ended \\
\hline Part-time coefficient & Hours worked as a fraction of full time work ( 1 in a full time job) \\
\hline Temporary Agency & 1 if the employment is signed through a temporary help agency \\
\hline Size of the firm & Dummies for 0 (missing), 1-19, 10-19,20-49,50-249, >250 \\
\hline Daily wage & $\begin{array}{l}\text { Real annual wage (gross salary) divided by the number of days worked in the year by } \\
\text { employer. For reliability we have applied a filter in } 1^{\text {st }} \text { and } 99^{\text {th }} \text { percentile to this } \\
\text { variable. It is a time-varying variable }\end{array}$ \\
\hline Public Sector & 1 if the employer is Public Sector \\
\hline
\end{tabular}

Source: Own elaboration

Note: Education level is constructed as a constant variable from the more recent LWLS given that from 2009 LWLS information for education level is more reliable.

Table A2: Sample selection

\begin{tabular}{lcc} 
& \multicolumn{1}{c}{ Number of individuals } \\
\hline \multicolumn{1}{c}{ Filters } & $\mathbf{2 0 0 5}$ sample & 2009 sample \\
\hline Individuals starting any job spell in the year of reference between 16 and 53 & 328,641 & 282,670 \\
years old & 233 & 0 \\
Drop individuals with lack of relevant information & 44,638 & 43,747 \\
Drop individuals from agriculture industry & 19,134 & 16,631 \\
After merging consecutive job spells, drop spells starting before the year of & 26,024 & 29,906 \\
reference & 4,478 & 6,382 \\
Drop spells shorter than 32 days and not real labour relationships & 5,319 & 6,518 \\
Drop learning or apprenticeship contracts & 52,396 & 38,333 \\
Drop overlapped spells and incidences & & $\mathbf{1 7 6 , 4 1 9}$ \\
Drop spells because of missing information of current type of contract $\left(^{*}\right)$ and & $\mathbf{1 4 1 , 1 5 3}$ \\
salaries lower than the 1st percentile or higher than 99th percentile. & & \\
\hline Final sample (number of individuals) & &
\end{tabular}

Source: Own elaboration from 2005-2007 LWLS and 2009-2011 LWLS.

Note: Data from fiscal module exclude information of Regime of household, individuals paying personal taxes in Basque Country and Navarra. 
Table A3: Estimation results of competing risks model with independent shared frailty terms with gamma distribution; 2005 and 2009 samples

\begin{tabular}{|c|c|c|c|c|c|c|}
\hline & & 2005 & & 2009 & & \\
\hline & Job & Unemp & Non-emp & Job & Unemp & Non-emp \\
\hline Unemployment rate & $\begin{array}{c}-2.374^{* * *} \\
(0.149)\end{array}$ & $\begin{array}{c}2.283^{* * *} \\
(0.163)\end{array}$ & $\begin{array}{c}-0.357^{* * *} \\
(0.124)\end{array}$ & $\begin{array}{l}-0.713^{* * *} \\
(0.124)\end{array}$ & $\begin{array}{l}1.393 * * * \\
(0.0822)\end{array}$ & $\begin{array}{c}-0.249 * * * \\
(0.0944)\end{array}$ \\
\hline Male & $\begin{array}{c}0.0791 * * * \\
(0.0120)\end{array}$ & $\begin{array}{c}-0.271 * * * \\
(0.0153)\end{array}$ & $\begin{array}{c}-0.0458 * * * \\
(0.0109)\end{array}$ & $\begin{array}{l}0.0531 * * * \\
(0.0142)\end{array}$ & $\begin{array}{l}-0.116^{* * *} \\
(0.0102)\end{array}$ & $\begin{array}{c}0.0135 \\
(0.0108)\end{array}$ \\
\hline Aged_16_19 & $\begin{array}{c}-0.319 * * * \\
(0.0264)\end{array}$ & $\begin{array}{c}-1.061 * * * \\
(0.0519)\end{array}$ & $\begin{array}{l}0.850 * * * \\
(0.0169)\end{array}$ & $\begin{array}{l}-0.478 * * * \\
(0.0554)\end{array}$ & $\begin{array}{l}-0.851^{* * *} \\
(0.0482)\end{array}$ & $\begin{array}{c}0.943 * * * \\
(0.0231)\end{array}$ \\
\hline Aged_20_24 & $\begin{array}{c}-0.0400^{* * *} \\
(0.0130)\end{array}$ & $\begin{array}{c}-0.233^{* * *} \\
(0.0189)\end{array}$ & $\begin{array}{l}0.416 * * * \\
(0.0119)\end{array}$ & $\begin{array}{l}-0.109 * * * \\
(0.0212)\end{array}$ & $\begin{array}{l}-0.159 * * * \\
(0.0162)\end{array}$ & $\begin{array}{c}0.458^{* * *} \\
(0.0147)\end{array}$ \\
\hline Aged_30_34 & $\begin{array}{c}-0.0714^{* * *} \\
(0.0128)\end{array}$ & $\begin{array}{c}0.0895^{* * *} \\
(0.0168)\end{array}$ & $\begin{array}{c}-0.138 * * * \\
(0.0136)\end{array}$ & $\begin{array}{l}-0.0724^{* * *} \\
(0.0189)\end{array}$ & $\begin{array}{l}0.0423^{* * *} \\
(0.0139)\end{array}$ & $\begin{array}{c}-0.176^{* * *} \\
(0.0160)\end{array}$ \\
\hline Aged_35_39 & $\begin{array}{c}-0.164 * * * \\
(0.0150)\end{array}$ & $\begin{array}{c}0.0914 * * * \\
(0.0186)\end{array}$ & $\begin{array}{c}-0.154 * * * \\
(0.0156)\end{array}$ & $\begin{array}{l}-0.133^{* * *} \\
(0.0210)\end{array}$ & $\begin{array}{l}0.0577 * * * \\
(0.0147)\end{array}$ & $\begin{array}{c}-0.198 * * * \\
(0.0177)\end{array}$ \\
\hline Aged_40_44 & $\begin{array}{c}-0.232 * * * \\
(0.0170)\end{array}$ & $\begin{array}{c}0.0902 * * * \\
(0.0200)\end{array}$ & $\begin{array}{c}-0.149 * * * \\
(0.0171)\end{array}$ & $\begin{array}{l}-0.173 * * * \\
(0.0234)\end{array}$ & $\begin{array}{l}0.0856 * * * \\
(0.0156)\end{array}$ & $\begin{array}{c}-0.214^{* * *} \\
(0.0194)\end{array}$ \\
\hline Aged_45_49 & $\begin{array}{c}-0.341^{* * *} \\
(0.0191)\end{array}$ & $\begin{array}{c}0.0697^{* * *} \\
(0.0212)\end{array}$ & $\begin{array}{c}-0.249 * * * \\
(0.0190)\end{array}$ & $\begin{array}{l}-0.219 * * * \\
(0.0257)\end{array}$ & $\begin{array}{l}0.0978 * * * \\
(0.0164)\end{array}$ & $\begin{array}{c}-0.247^{* * *} \\
(0.0211)\end{array}$ \\
\hline Aged_50_55 & $\begin{array}{c}-0.471^{* * *} \\
(0.0247)\end{array}$ & $\begin{array}{l}0.124 * * * \\
(0.0249)\end{array}$ & $\begin{array}{c}-0.237 * * * \\
(0.0237)\end{array}$ & $\begin{array}{l}-0.330^{* * *} \\
(0.0315)\end{array}$ & $\begin{array}{l}0.105^{* * *} \\
(0.0187)\end{array}$ & $\begin{array}{c}-0.251^{* * *} \\
(0.0250)\end{array}$ \\
\hline $\begin{array}{l}\text { Spanish speakers } \\
\text { immigrants }\end{array}$ & $\begin{array}{l}0.172^{* * *} \\
(0.0192)\end{array}$ & $\begin{array}{c}-0.317^{* * *} \\
(0.0301)\end{array}$ & $\begin{array}{l}0.309 * * * \\
(0.0187)\end{array}$ & $\begin{array}{l}0.00551 \\
(0.0284)\end{array}$ & $\begin{array}{l}0.0203 \\
(0.0192)\end{array}$ & $\begin{array}{l}0.322^{* * *} \\
(0.0207)\end{array}$ \\
\hline $\begin{array}{l}\text { Non Spanish speakers } \\
\text { immigrants }\end{array}$ & $\begin{array}{c}0.0763^{* * *} \\
(0.0187)\end{array}$ & $\begin{array}{l}-0.101^{* * *} \\
(0.0257)\end{array}$ & $\begin{array}{l}0.335^{* * *} \\
(0.0179)\end{array}$ & $\begin{array}{l}0.0407^{*} \\
(0.0214)\end{array}$ & $\begin{array}{l}-0.113^{* * *} \\
(0.0149)\end{array}$ & $\begin{array}{l}0.317^{* * *} \\
(0.0158)\end{array}$ \\
\hline Children_4 & $\begin{array}{l}-0.0253 * \\
(0.0136)\end{array}$ & $\begin{array}{c}0.0849 * * * \\
(0.0166)\end{array}$ & $\begin{array}{l}-0.00682 \\
(0.0137)\end{array}$ & $\begin{array}{l}-0.0344^{*} \\
(0.0190)\end{array}$ & $\begin{array}{l}0.0757^{* * *} \\
(0.0126)\end{array}$ & $\begin{array}{c}-0.0742^{* * *} \\
(0.0158)\end{array}$ \\
\hline Children_15 & $\begin{array}{l}-0.0115 \\
(0.0119)\end{array}$ & $\begin{array}{c}0.0366 * * * \\
(0.0135)\end{array}$ & $\begin{array}{c}-0.0630 * * * \\
(0.0121)\end{array}$ & $\begin{array}{l}0.0263 \\
(0.0163)\end{array}$ & $\begin{array}{l}0.0558^{* * *} \\
(0.0104)\end{array}$ & $\begin{array}{l}-0.112^{* * *} \\
(0.0138)\end{array}$ \\
\hline Primary_education & $\begin{array}{l}-0.0210^{*} \\
(0.0122)\end{array}$ & $\begin{array}{l}0.0258 * \\
(0.0143)\end{array}$ & $\begin{array}{c}0.0957 * * * \\
(0.0115)\end{array}$ & $\begin{array}{l}-0.0469 * * \\
(0.0185)\end{array}$ & $\begin{array}{l}0.0911^{* * *} \\
(0.0110)\end{array}$ & $\begin{array}{c}0.0209 \\
(0.0137)\end{array}$ \\
\hline Upper-secondary & $\begin{array}{c}-0.0235^{* *} \\
(0.0115)\end{array}$ & $\begin{array}{c}-0.142^{* * *} \\
(0.0146)\end{array}$ & $\begin{array}{l}0.107 * * * \\
(0.0109)\end{array}$ & $\begin{array}{l}0.0191 \\
(0.0166)\end{array}$ & $\begin{array}{l}-0.142 * * * \\
(0.0117)\end{array}$ & $\begin{array}{l}0.131^{* * *} \\
(0.0127)\end{array}$ \\
\hline Post-secondary & $\begin{array}{c}0.0229 \\
(0.0147)\end{array}$ & $\begin{array}{c}-0.480 * * * \\
(0.0210)\end{array}$ & $\begin{array}{l}0.215^{* * *} \\
(0.0133)\end{array}$ & $\begin{array}{l}0.0561^{* * *} \\
(0.0204)\end{array}$ & $\begin{array}{l}-0.462 * * * \\
(0.0169)\end{array}$ & $\begin{array}{c}0.157^{* * *} \\
(0.0157)\end{array}$ \\
\hline Inhabitants $>40,000$ & $\begin{array}{c}-0.0393 * * * \\
(0.00879)\end{array}$ & $\begin{array}{l}0.0236^{* *} \\
(0.0110)\end{array}$ & $\begin{array}{c}-0.0708^{* * *} \\
(0.00836)\end{array}$ & $\begin{array}{l}-0.0584^{* * *} \\
(0.0128)\end{array}$ & $\begin{array}{l}0.0176 * * \\
(0.00872)\end{array}$ & $\begin{array}{c}-0.0435 * * * \\
(0.00987)\end{array}$ \\
\hline Non manual & $\begin{array}{c}-0.0613^{* * *} \\
(0.0113)\end{array}$ & $\begin{array}{c}-0.250 * * * \\
(0.0142)\end{array}$ & $\begin{array}{c}-0.198 * * * \\
(0.0103)\end{array}$ & $\begin{array}{l}-0.0244 \\
(0.0158)\end{array}$ & $\begin{array}{l}-0.294 * * * \\
(0.0114)\end{array}$ & $\begin{array}{c}-0.102^{* * *} \\
(0.0118)\end{array}$ \\
\hline Construction & $\begin{array}{c}-0.0508^{* * *} \\
(0.0124)\end{array}$ & $\begin{array}{c}-0.323 * * * \\
(0.0170)\end{array}$ & $\begin{array}{c}-0.310^{* * *} \\
(0.0131)\end{array}$ & $\begin{array}{l}-0.142^{* * *} \\
(0.0202)\end{array}$ & $\begin{array}{l}0.216 * * * \\
(0.0129)\end{array}$ & $\begin{array}{c}-0.235^{* * *} \\
(0.0169)\end{array}$ \\
\hline Manufacturing & $\begin{array}{c}-0.324^{* * *} \\
(0.0162)\end{array}$ & $\begin{array}{l}0.00492 \\
(0.0179)\end{array}$ & $\begin{array}{c}-0.272^{* * *} \\
(0.0156)\end{array}$ & $\begin{array}{l}-0.253^{* * *} \\
(0.0261)\end{array}$ & $\begin{array}{l}0.0139 \\
(0.0161)\end{array}$ & $\begin{array}{c}-0.245^{* * *} \\
(0.0216)\end{array}$ \\
\hline
\end{tabular}


Table A3, continued

\begin{tabular}{|c|c|c|c|c|c|c|}
\hline & \multicolumn{3}{|c|}{2005} & \multicolumn{3}{|c|}{2009} \\
\hline & Job & Unemp & Non-emp & Job & Unemp & Non-emp \\
\hline \multirow[t]{2}{*}{ Open-ended } & $-0.891^{* * *}$ & $0.744^{* * *}$ & $-0.304 * * *$ & $-0.886 * * *$ & $0.349 * * *$ & $-0.296 * * *$ \\
\hline & $(0.0389)$ & $(0.0203)$ & $(0.0253)$ & $(0.0417)$ & $(0.0162)$ & $(0.0231)$ \\
\hline \multirow[t]{2}{*}{ Permanent } & $-1.439 * * *$ & $-2.023 * * *$ & $-1.973 * * *$ & $-1.183^{* * *}$ & $-1.704^{* * *}$ & $-1.803^{* * *}$ \\
\hline & $(0.0127)$ & (0.0193) & $(0.0150)$ & $(0.0172)$ & $(0.0154)$ & $(0.0171)$ \\
\hline \multirow[t]{2}{*}{ On-call Temporary } & $-0.124 * * *$ & $-0.302^{* * *}$ & $0.0682 * * *$ & 0.0263 & $-0.178 * * *$ & $0.201 * * *$ \\
\hline & $(0.0223)$ & $(0.0247)$ & $(0.0187)$ & $(0.0266)$ & $(0.0187)$ & $(0.0195)$ \\
\hline \multirow{2}{*}{$\begin{array}{l}\text { Dummy missing firm } \\
\text { size }\end{array}$} & $0.969 * * *$ & $0.454 * * *$ & $0.479 * * *$ & $0.980 * * *$ & $0.634 * * *$ & $0.615^{* * *}$ \\
\hline & $(0.0172)$ & $(0.0262)$ & $(0.0179)$ & $(0.0310)$ & $(0.0237)$ & $(0.0241)$ \\
\hline \multirow[t]{2}{*}{ size_10_19 } & $-0.0512 * * *$ & $-0.148 * * *$ & $-0.0802 * * *$ & $-0.107^{* * *}$ & $-0.174 * * *$ & $-0.121 * * *$ \\
\hline & $(0.0145)$ & $(0.0185)$ & $(0.0142)$ & $(0.0210)$ & $(0.0142)$ & $(0.0168)$ \\
\hline \multirow[t]{2}{*}{ size_20_49 } & $-0.113^{* * *}$ & $-0.237 * * *$ & $-0.121^{* * *}$ & $-0.176 * * *$ & $-0.219 * * *$ & $-0.141 * * *$ \\
\hline & $(0.0135)$ & $(0.0171)$ & $(0.0131)$ & $(0.0198)$ & $(0.0135)$ & (0.0156) \\
\hline \multirow[t]{2}{*}{ size_50_249 } & $-0.247 * * *$ & $-0.241 * * *$ & $-0.125^{* * *}$ & $-0.332 * * *$ & $-0.284 * * *$ & $-0.175^{* * *}$ \\
\hline & $(0.0132)$ & (0.0159) & $(0.0123)$ & $(0.0189)$ & $(0.0128)$ & $(0.0143)$ \\
\hline \multirow[t]{2}{*}{ size_250 } & $-0.379 * * *$ & $-0.338 * * *$ & $-0.124 * * *$ & $-0.537 * * *$ & $-0.370 * * *$ & $-0.231 * * *$ \\
\hline & $(0.0150)$ & $(0.0182)$ & $(0.0134)$ & $(0.0217)$ & $(0.0150)$ & $(0.0161)$ \\
\hline \multirow[t]{2}{*}{ High_technology } & $0.0833^{* * *}$ & $-0.119 * * *$ & $-0.0691^{* * *}$ & $0.0610^{*}$ & $-0.0579 * *$ & $-0.132 * * *$ \\
\hline & $(0.0165)$ & $(0.0224)$ & $(0.0163)$ & $(0.0358)$ & $(0.0290)$ & $(0.0335)$ \\
\hline \multirow[t]{2}{*}{ Temporary Agency } & $1.097 * * *$ & $0.155^{* * *}$ & $0.390 * * *$ & $1.133 * * *$ & $0.245^{* * *}$ & $0.414 * * *$ \\
\hline & $(0.0178)$ & $(0.0300)$ & $(0.0180)$ & $(0.0277)$ & $(0.0254)$ & $(0.0241)$ \\
\hline \multirow[t]{2}{*}{ Public Sector } & $-0.536 * * *$ & $0.211 * * *$ & -0.0186 & $-0.285^{* * *}$ & $0.166 * * *$ & -0.0165 \\
\hline & $(0.0228)$ & $(0.0212)$ & $(0.0173)$ & $(0.0260)$ & $(0.0162)$ & $(0.0179)$ \\
\hline \multirow[t]{2}{*}{ In_daily_salary } & $0.173 * * *$ & $0.138 * * *$ & $-0.231 * * *$ & $0.235 * * *$ & $0.0611 * * *$ & $-0.137 * * *$ \\
\hline & $(0.0124)$ & $(0.0153)$ & $(0.0113)$ & $(0.0166)$ & $(0.0118)$ & (0.0123) \\
\hline \multirow[t]{2}{*}{ Part time coef. } & $0.127^{* * *}$ & $0.729 * * *$ & $-0.611 * * *$ & $-0.154 * * *$ & $0.559 * * *$ & $-0.757 * * *$ \\
\hline & $(0.0298)$ & $(0.0374)$ & $(0.0237)$ & $(0.0377)$ & $(0.0276)$ & $(0.0261)$ \\
\hline \multirow[t]{2}{*}{ Ln Theta } & $-1.459 * * *$ & -15.13 & $-1.312^{* * *}$ & $-0.903 * * *$ & $-3.478 * * *$ & $-1.336 * * *$ \\
\hline & $(0.0488)$ & $(170.6)$ & $(0.0425)$ & $(0.0571)$ & $(0.405)$ & $(0.0557)$ \\
\hline Observations & 903,147 & 903,147 & 903,147 & 715,705 & 715,705 & 715705 \\
\hline Number of groups & 176,419 & 176,419 & 176,419 & 141,153 & 141,153 & 141153 \\
\hline Number of exits & 63,314 & 35,476 & $73,016.00$ & 29,627 & 57,825 & 51,015 \\
\hline LogLikelihood & -161984 & -100688 & -183439 & $-92,785$ & $-131,362$ & -134258 \\
\hline theta & 0.232 & $2.70 e-07$ & 0.269 & 0.405 & 0.0309 & 0.263 \\
\hline
\end{tabular}

Note: Piecewise baseline and shared frailty assuming Gamma distribution for unobserved heterogeneity. Both 2005 and 2009 LR test show that frailty is significant ( $p$-value $=0.000)$. References categories: female, Native Spanish, low skilled level, manual occupation, Aged_25_29, services sector, size_1_9, temporary contract. Age, unemployment rate, dependent children and daily salary are time-varying variables.

Significant levels: ${ }^{* *} p<0.01, * * p<0.05, * p<0.1$ 


\section{References}

Alba-Ramirez A (1991) Job losses, unemployment duration and new jobs in Spain. Labour $5(1): 23-43$.

Alba A, Arranz JM, Muñoz-Bullón F (2012) Re-employment probabilities of unemployment benefit recipients. Applied Economics 44(28):3645-3664.

Amuedo-Dorantes C, Malo MA, Muñoz-Bullón F (2008) The Role of Temporary Help Agency Employment on Temp-to-Perm. Journal of Labor Research 29(2):138-161.

Arranz JM, García-Serrano C (2004) The influence of previous labour market experiences on subsequent job tenure. Hacienda Pública Española, 168(1):47-68.

Arranz JM, García-Serrano C (2011) Are the MCVL tax data useful? Ideas for mining. Hacienda Pública Española 199(4):151-186.

Arranz JM, García-Serrano C (2012) Diferencias salariales, características del puesto de trabajo y cualificación: Un análisis para el período 2005-2010. Presupuesto y Gasto Público 67:195-212.

Bachman (2005) Labour market dynamics in Germany: Hirings, separations, and Job-toJob Transitions over the Business Cycle. SPB 649 Discussion Paper 2005-045.

Bergmann A, Mertens A (2011) Job Stability Trends, Lay-offs, and Transitions to Unemployment in West Germany. Labour 25(4):421-446.

Bijwaard GE (2014) Unobserved heterogeneity in Multiple-Spell Multiple-States Duration Models, Demographic Research, 30(58):1591-1620.

Bijwaard GE, Wahba J (2014), Do High-Income or Low-Income Immigrants Leave Faster? Journal of Development Economics, 108(May):54-68.

Blázquez-Cuesta M (2008) Low-wage employment and mobility in Spain. Labour 22(1):115-146.

Boockmann B, Hagen T (2008) Fixed term contracts as sorting mechanism: Evidence from job durations in West Germany. Labour Economics 15(5):984-1005.

Boockmann B, Steffes S (2010) Workers, Firms, or Institutions: What Determines Job Duration for Male Employees in Germany? Industrial and Labor Relations Review 64(1): 109-127.

Booth A, Francesconi M, García-Serrano C (1999) Job tenure and job mobility in Britain. Industrial and Labor Relations Review 53(1):43-70. 
Bover O, Arellano M, Bentolila S (2002) Unemployment duration, benefit duration and the business cycle. Economic Journal 112(479):223-265.

Bowlus A (1995) Matching workers and jobs: Cyclical fluctuations in match quality. Journal of Labour Economics 13 (2):335-350.

Bratberg E, Salvanes K, Vaage K (2010) Has job stability decreased? Population data from a small open economy. Scandinavian Journal of Economics 112(1):163-183.

Burdett K and Mortensen D (1998) The Employer Size-Wage Effect. Journal of Political Economy 97(5):1027-1059.

Burgess S, Lane J, Stevens D (1999) Job flows, worker flows and churning. Journal of Labor Economics 18(3):473-502.

Burgess S, Lane J, Stevens D (2001) Churning dynamics: An analysis of hires and separations at the employer level. Labour Economics 8(1):1-15.

Consejo Empresarial para la Competitividad (2014). España 2018. http://www.iefamiliar.com/web/es/consejo2.html

Cueto B, Rodríguez V, La antigüedad de los indefinidos despedidos en España. ¿Hay un antes y un después de la reforma laboral de 2010? Cuadernos de Economía (2011). http://dx.doi.org/10.1016/j.cesjef.2013.08.003

Davis S, Haltiwanger J (1990) Gross Job Creation and Destruction: Microeconomic Evidence and Macroeconomic Implications NBER Macroeconomics Annual V:123-168.

Davis S, Haltiwanger (2001) Sectoral Job Creation and Destruction Responses to Oil Price Changes and Other Shocks. Journal of Monetary Economics 48(3):465-512.

Davis S, Haltiwanger J (2014) Labor Market Fluidity and Economic Performance. NBER Working Paper № 20479.

De la Roca J (2014) Wage cyclicality: Evidence from Spain using social security data. SERIEs 5(2-3):173-195.

Devereux PJ (2002) Occupational Upgrading and the business cycle. Labour 16(3):423452.

Devereux PJ (2004) Cyclical Quality Adjustment in the Labor Market. Southern Economic Journal 70(3):600-615.

Dolado JJ, García-Serrano C, Jimeno JF (2002) Drawing lessons from the boom of temporary jobs in Spain. The Economic Journal 112(480):270-295. 
Dustmann C, Glitz A, Vogel T (2010) Employment, wages, and the economic cycle: Differences between immigrants and natives. European Economic Review 54(1):1-17. Dütsch M, Struck O (2014) Employment Trajectories in Germany: Do Firm Characteristics and Regional Disparities Matter? Journal for Labour Market Research 47(1-2): 107-127. Eurofound (2013) Employment polarisation and job quality in the crisis: European Jobs Monitor 2013, Eurofound, Dublin.

European Commission (2015) Country Report Spain 2015 Including an In-Depth Review on the prevention and correction of macroeconomic imbalances. Commission Staff Working Document. ttp://ec.europa.eu/europe2020/pdf/csr2015/cr2015_spain_en.pdf Fort T, Haltiwanger J, Jarmin R, Miranda J (2013) How Firms Respond to Business Cycles: The Role of Firm Age and Firm Size. IMF Economic Review 61(3):520-559.

Frederiksen A, Westergaard-Nielsen N (2007) Where did they go? Modelling transitions out of jobs. Labour Economics 14(5):811-828.

Frederiksen A (2008) Gender differences in job separation rates and employment stability: New evidence from employer-employee data. Labour Economics 15(5):915-937. García-Pérez JI (1997) Las tasas de salida del empleo y el desempleo en España 19781993. Investigaciones Economicas XXI(1):29-53.

García-Perez JI, Muñoz-Bullón F (2005) Are temporary help agencies changing mobility patterns in the Spanish labour market? Spanish Economic Review 7(1):43-65.

García-Posada M, Mora J (2013) Firm Size and judicial efficacy: evidence for the new civil procedures in Spain. Working paper 1303, Madrid: Banco de España.

García-Serrano C (2012) Del pasmo al marasmo: El sector de la construcción y su relación con la crisis del empleo. Estudios de Economia Aplicada 30(1):163-182.

García-Serrano C, Malo MA (1996) Desajuste educativo y movilidad laboral en España. Revista de Economía Aplicada 11 (4):105-131.

Gertler M, Gilchrist S (1994) Monetary Policy, Business Cycles, and the Behaviour of Small Manufacturing Firms. Quarterly Journal of Economics 109(2):309-340.

Haltiwanger J, Hyatt H, McEntarfer E (2015) Cyclical Reallocation of Workers across Employers by Firm Size and Firm Wage. NBER Working Paper 21235. 
Heinz, W (2006) From work trajectories to negotiated careers: the contingent work life course. In: Mortimer, J.T., Shanahan, M.J. (eds.) Handbook of the Life Course, pp. 185204. Springer, New York.

Heckman J, Singer B (1984) The identifiability of the proportional hazard model.

Review of Economic Studies 51(2):231-241.

Hirsch B, Schnable C (2012) Women Move Differently: Job Separations and Gender. Journal of Labor Research, 33(4):417-442.

Hyatt H, McEntarfer (2012) E Job-to-Job Flows in the Great Recession. The American Economic Review Papers and Proceedings 102(3):580-583.

Huerta E, Salas V (2014) Tamaño de las empresas y productividad de la economía española. Un análisis exploratorio. Mediterráneo Económico vol.25, Almería: Fundación Cajamar.

Jovanovic B (1979) Job Matching and the Theory of Turnover. Journal of Political Economy 87(5):972-990.

Kahn L, McEntarfer E (2014) Employment Cyclicality and Firm Quality. NBER Working Paper 20698.

Kalbfleisch JD, Prentice RL (2002) The statistical analysis of failure time data. Second Edition. New York: Wiley.

Kalwij A (2004) Unemployment experiences of young men: on the road to stable employment? Oxford Bulletin of Economics and Statistics 66(2):205-237.

Keith K, McWilliams A (1995) The Wage Effects of Cumulative Job Mobility. Industrial and Labor Relations Review 71 (4):121-137.

Lentz R, Mortensen D (2005) Productivity growth and worker reallocation. International Economic Review 46(3):731-749.

Longhi S, Taylor M (2013) Occupational Change and Mobility among Employed and Unemployed Job Seekers, Scottish Journal of Political Economy, 60(1):71-100.

Martin C (2003) Explaining Labour Turnover: Empirical Evidence from UK Establishments. Labour 17(3):391-412.

Moscarini G, Postel-Vinay F (2009) The Timing of Labor Market Expansions: New Facts and a New Hypothesis. In NBER Macroeconomics Annual 2009, Vol. 23, ed. Daron Acemoglu, Kenneth Rogoff, and Michel Woodford, 1-52. Chicago: University of Chicago Press. 
Moscarini G, Postel-Vinay F (2012) The Contribution of Large and Small Employers to Job Creation in Times of High and Low Unemployment. American Economic Review 102(6):2509-2539.

Moscarini G, Postel-Vinay F (2013) Stochastic Search Equilibrium. Review of Economic Studies 80(4):1545-1581.

Nagore A, van Soest A (2014) Unemployment transitions to stable and unstable jobs before and during the crisis. IZA DP № 8121.

Nickell S (1979) Estimating the Probability of Leaving Unemployment. Econometrica 47(5):1249-1266.

Pérez F (2014) Crecimiento y competitividad: Los desafíos de un desarrollo inteligente. Informe Fundación BBVA-Ivie.

Rebitzer J (1986) Establishment size and job tenure. Industrial Relations: A Journal of Economy and Society 25(3):292-302.

Rebollo Y (2012) Unemployment insurance and job turnover in Spain. Labour Economics 19(3):403-426.

Rocha F, Aragón J (2012) La Crisis económica y sus efectos sobre el empleo en España. Fundación 1을 de Mayo. Colección Informes.

Shane S (2009) Why encouraging more people to become entrepreneurs is bad public policy. Small Business Economics 33(2):141-149.

Sharpe S (1994) Financial Market Imperfections, Firm Leverage, and the Cyclicality of Employment. American Economic Review 125(3):1253-1296

Silva JI, Vázquez-Grenno J (2013) The Ins and Outs of Unemployment in a Two-Tier Labor Market. Labour Economics 24(January 2005):161-169.

Stigler GJ (1962) Information in the Labor Market. Journal of Political Economy 70(5):S94S105.

Struck O (2006) Flexibilität und Sicherheit. Empirische Befunde, theorische Konzepte und institutionelle Gestaltung von Beschäftigungsstabilität. VS-Verlag, Wiesbaden.

Teulings C (1993) The diverging effects of the Business cycle on the expected duration of job search. Oxford Economic papers 45(3):482-500. 
Theodossiou I, Zangelidis A (2009) Should I stay or should I go? The effect of gender, education and unemployment on labour market transitions. Labour Economics 16(5):566577.

Van den Berg, GJ (2001) Duration models: Specification, identification, and multiple duration. In J. Heckman and E Leamer (Eds.), Handbook of Econometrics, Vol. V. Amsterdam: North-Holland, pp.3381-3460.

Van Ours JC, Ridder G (1995) Job matching and job competition: Are lower educated workers at the back of the queues? European Economic Review 39(9):1717-1731 Verho J (2014) Unemployment duration and the role of compositional variation: evidence from a period of economic crisis in Finland. Empirical Economics 47:35-56. 